\title{
ARTICLE
}

\section{Transduction of group I mGluR-mediated synaptic plasticity by $\beta$-arrestin2 signalling}

\author{
Andrew G. Eng ${ }^{1}$, Daniel A. Kelver ${ }^{1}$, Tristan P. Hedrick ${ }^{1} \&$ Geoffrey T. Swanson ${ }^{1}$
}

Conventional signalling by the group I metabotropic glutamate receptors, mGluR1 and mGluR5, occurs through G-protein coupling, but evidence suggests they might also utilize other, non-canonical effector pathways. Here we test whether group I mGluRs require $\beta$-arrestin signalling during specific forms of plasticity at hippocampal excitatory synapses. We find that genetic ablation of $\beta$-arrestin2, but not $\beta$-arrestin1, results in deficits in plasticity mediated by mGlu1 receptors in CA3 pyramidal neurons and by mGlu5 receptors in CA1 pyramidal neurons. Pharmacological studies additionally support roles for Src kinases and MAPK/ERK downstream of $\beta$-arrestin2 in CA3 neurons. mGluR1 modulation of intrinsic conductances is otherwise preserved in $\beta$-arrestin2 ${ }^{-/}$mice with the exception of a rebound depolarization, and non-mGluR-mediated long-term potentiation is unaltered. These results reveal a signalling pathway engaged by group I mGluRs to effect changes in synaptic and cell intrinsic physiology dependent upon $\beta$-arrestin rather than $G$ proteins. Pharmacological manipulation of mGluRs with effector-biased ligands could lead to novel therapies to treat neurological disease.

\footnotetext{
${ }^{1}$ Department of Pharmacology, Northwestern University Feinberg School of Medicine, Chicago, Illinois 60611, USA. Correspondence and requests for materials should be addressed to G.T.S. (email: gtswanson@northwestern.edu).
} 
G roup I metabotropic glutamate receptors (mGluR1 and mGluR5) function as modulators of neuronal physiology and synaptic transmission and have been the target of therapeutic drug development for pathologies including Fragile X syndrome, epilepsy and pain ${ }^{1}$. mGlu1/5 receptors are seven transmembrane receptors (7TMRs) that differ from other mGluRs in their preferential coupling to $G \alpha_{q / 11}$ second messenger pathways, yet mGlul receptors in particular exhibit an intriguing ability to drive cellular responses even when G-protein activity is inhibited pharmacologically ${ }^{2-6}$. G-proteinindependent signalling by other 7TM receptors (for example, angiotensin type $1 \mathrm{~A}$ receptors and $\beta_{2}$-adrenergic receptors) is transduced by kinase cascades whose activity is initiated by 7TM receptor coupling to the cytoplasmic scaffolding proteins $\beta$-arrestin1 and $2^{7,8}$, but how the arrestins participate in mGluR signalling and specifically in modification of neuronal synaptic and intrinsic activity remains unclear.

mGlu1 and mGlu5 receptors are widely distributed among excitatory synapses in the central nervous system and respond to glutamate most notably by $G$ protein-mediated stimulation of phosphoinositide hydrolysis, mobilization of calcium from intracellular stores, and activation of protein kinase C. Protein kinase $\mathrm{C}$ has a well-established role in some forms of synaptic plasticity that include long-term depression (LTD) of cerebellar parallel fibre-Purkinje cell synaptic transmission ${ }^{9}$ and mGluR5-mediated selective long-term potentiation (LTP) of $\mathrm{N}$-methyl-D-aspartate (NMDA) receptor-mediated currents at hippocampal mossy fibre-CA3 synapses ${ }^{10}$. G protein-dependent signalling by mGluR1/5 also alters neuronal excitability, in some instances through slow currents carried by transient receptor potential (TRP)-like channels ${ }^{11}$. Not all mGluR1/5 signalling appears to be mediated by $\mathrm{G}$ proteins, however. Some aspects of mGluR1 signalling are intact in conditions where $\mathrm{G}$ proteins were pharmacologically inhibited using non-hydrolyzable forms of GDP or $N$-ethylmaleimide ${ }^{4-6}$. GDPßS-resistant signalling by mGlu1 receptors in CA3 pyramidal neurons, for example, underlies transient potentiation of NMDA currents and intermediate-term potentiation of transmission at mossy fibre synapses ${ }^{2,3}$.

In this study, we asked whether $\beta$-arrestin scaffolding proteins serve as molecular substrates of mGluR synaptic and intrinsic plasticity in a $G$ protein-independent manner. We found that at least two distinct forms of group I mGluR-dependent hippocampal synaptic plasticity were abrogated in $\beta$-arrestin $2^{-1-}$ but not $\beta$-arrestin $1^{-/-}$mice. In pharmacological antagonism studies, we identify mitogen-activated protein kinase (MAPK)/ extracellular signal-regulated kinase (ERK) and Src as downstream kinases in an mGluR1- $\beta$-arrestin2 signalling network. Non-synaptic functions of mGlul receptors were differentially impacted in $\beta$-arrestin $2^{-l-}$ mice. Our data demonstrate that group I mGluRs employ a $\beta$-arrestin2-mediated signalling mode to alter synaptic strength and suggest that selective targeting of mGluR signalling modalities could be a viable therapeutic strategy in the future.

\section{Results}

mGluR1 plasticity at CA3 synapses is $\beta$-arrestin2 dependent. We initially tested the contribution of $\beta$-arrestins to a selectively mGluR1-dependent form of intermediate-term potentiation of excitatory post-synaptic currents at mossy fibre-CA3 synapses. mGluR1 dependence was previously characterized using mGluR1 ${ }^{-1-}$ mice and selective antagonists of mGlu1 and mGlu5 receptors ${ }^{3}$. In the current study, we compared electrophysiological recordings from acute hippocampal slices prepared from wild-type and $\beta$-arrestin ( $\beta$ arr) knockout mice. Baseline mossy fibre- excitatory post-synaptic current(mfEPSC) amplitudes were obtained by delivering pairs of electrical stimuli to mossy fibre axons in the stratum lucidum at a basal frequency $(0.05 \mathrm{~Hz})$ for $10 \mathrm{~min}$. mGluR1-dependent potentiation of excitatory postsynaptic currents (EPSCs) was induced by delivering paired pulses at $1 \mathrm{~Hz}$ for $2 \mathrm{~min}$ (paired pulse low-frequency stimulation, PP-LFS; Fig. 1a). mfEPSCs were then evoked at basal frequency for 30 min after the train. At the conclusion of each mossy fibre-CA3 plasticity experiment, we verified contribution from mossy fibre inputs by selectively inhibiting mossy fibre transmission with group II mGluR agonist $\left(2 S, 2^{\prime} R, 3^{\prime} R\right)-2-\left(2^{\prime}, 3^{\prime}\right.$-dicarboxycyclopropyl) glycine (DCG-IV, $1 \mu \mathrm{M})$. All data collection, posthoc analysis, and imposition of inclusion criteria were performed with the experimenter blinded to genotype.

Consistent with previous observations, EPSC amplitudes measured in wild-type animals $25-30 \mathrm{~min}$ post-train remained elevated when compared with baseline values $(131 \pm 7 \%$ of baseline amplitudes in $\beta a r r 2^{+1+}$ animals, $n=11$ ) (ref. 3). However, mGluR1-mediated prolonged potentiation was absent in $\beta a r r 2^{-1-}$ animals, such that post-train amplitudes were reduced compared with wild type $(94 \pm 9 \%$ of baseline amplitudes, $n=13, P=0.009$, Fig. $1 \mathrm{~b}, \mathrm{f})$. Normalized post-train amplitudes measured in individual experiments were plotted in a cumulative probability histogram (Fig. 1c). Neither frequency facilitation during the train $\left(400 \pm 34 \%\right.$ for $\beta$ arr $2^{+1+}, n=11$, $325 \pm 26 \%$ for $\beta$ arr2 $\left.2^{-I}, n=13 ; P=0.13\right)$ nor baseline paired pulse ratios (PPRs) were different in recordings from $\beta$ arr $2^{-1-}$ and $\beta$ arr $2^{+l+}$ littermates $\left(2.4 \pm 0.1\right.$ in $\beta$ arr ${ }^{+l+}, n=11$; $2.4 \pm 0.2$ in $\beta$ arr $2^{-1-}$ animals, $n=13 ; P=0.54$, Fig. $1 \mathrm{~g}$ ).

In contrast, PP-LFS-induced potentiation of mfEPSCs was intact in $\beta$ arr1 $1^{-/}$mice $\left(143 \pm 6 \%\right.$ for $\beta$ arr1 ${ }^{+/+}, n=10$; $137 \pm 14 \%$ for $\beta$ arr $1^{-l-} ; n=14, P=0.22$, Fig. $\left.1 \mathrm{~d}-\mathrm{f}\right)$. Pre-train PPRs were not different between $\beta$ arrl ${ }^{+1+}$ and $\beta$ arr1 $1^{-1-}$ groups $\left(2.5 \pm 0.2\right.$ in $\beta a r r 1^{+1+}, n=10 ; 2.6 \pm 0.2$ in $\beta a r r 1^{-/-}$ animals, $n=14 ; P=0.91$, Fig. $1 \mathrm{~g}$ ), as was frequency facilitation at

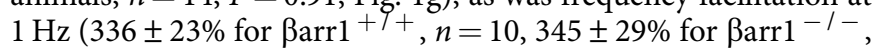
$n=14 ; P=0.93)$. These data demonstrate that PP-LFS, mGluR1mediated plasticity of mossy fibre-CA3 synapses is dependent specifically on $\beta$ arr2.

mGlu1 receptors and $\beta$-arrestin2 associate in brain tissue. We tested whether $\beta$ arr2 and mGlu1 receptors associate in native tissue in immunoprecipitation experiments using brain tissue homogenates prepared from wild-type and $\mathrm{mGluR}^{-1-}$ mice. ßarr2, a $46 \mathrm{kDa}$ protein, readily co-immunoprecipitated mGlu1 receptor protein, which resolved as monomers $(142 \mathrm{kDa})$ and dimers $(>250 \mathrm{kDa})$, in the cortex, hippocampus and cerebellum of wild-type mice. In control experiments, mGluR1 immunoreactivity was absent when an IgG isotype antibody was used for immunoprecipitation $(n=3$, representative blot in Fig. $1 \mathrm{~h}$, uncropped blot in Supplementary Fig. 1) or when ßarr2 immunoprecipitation was performed on brain membrane preparations from mGluR $1^{-I-}$ mice $(n=3$, representative blot in Supplementary Fig. 2). Immunoblotting of lysates confirmed the presence of mGlu1 receptors in wild type but not mGluR1 ${ }^{-1-}$ tissue, whereas $\beta$ arr2 was detected in immunoprecipitation and input conditions for both genotypes. These results support an association between $\beta$ arr2 and mGlu1 receptors in neurons.

Role of Src and other kinases in mGluR1-mediated plasticity. PP-LFS of mossy fibre-CA3 synapses induces plasticity that selectively requires mGlu1 receptors and $\beta$ arr2, and consequently we sought to test the role of downstream constituents associated with $\beta$ arr2 signalling. Src family kinases seemed likely candidates given their association with $\beta$-arrestins following $\beta_{2}$-adrenergic 
a

mGluR1-mediated potentiation of mfEPSCs

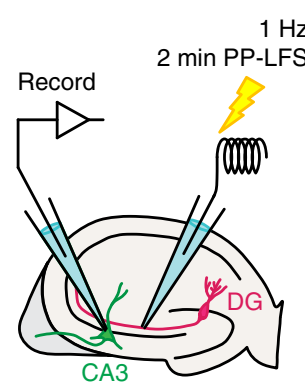

b

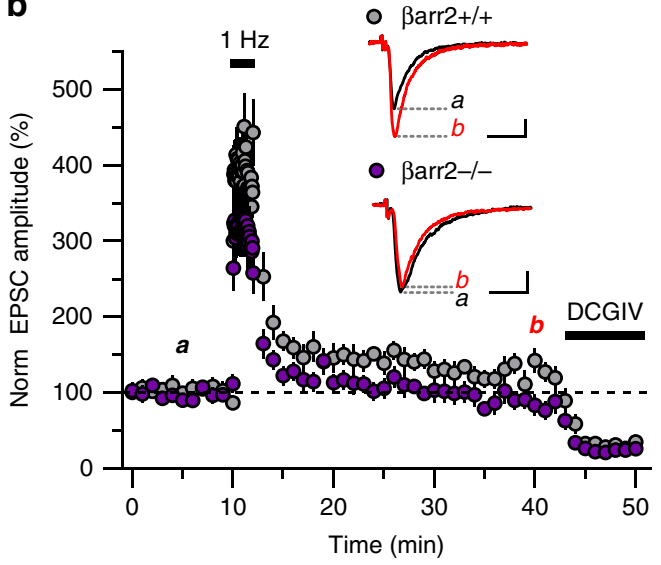

C o Barr2+/+ o Barr2-/-

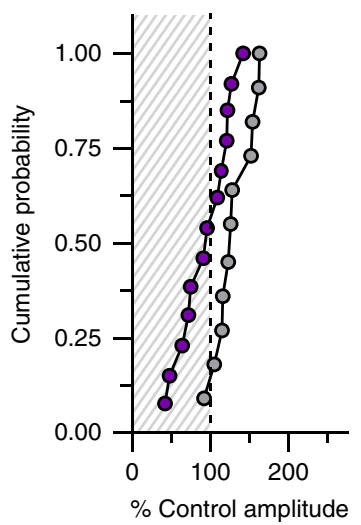

d

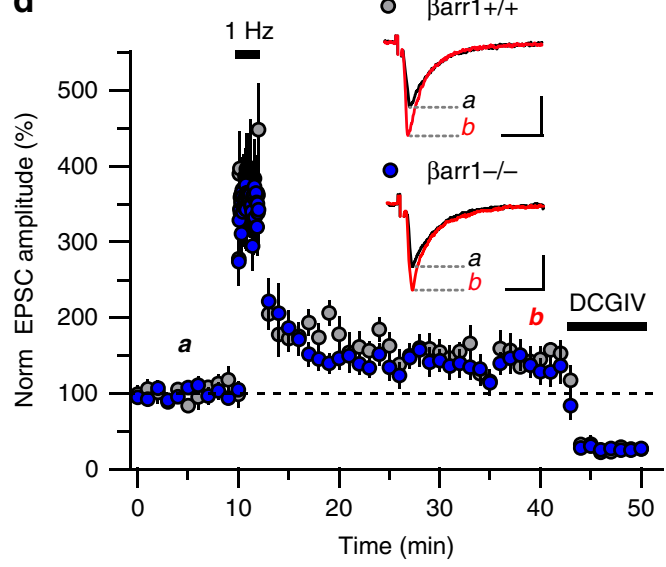

e $\circ$ Barr1+/+ $\bullet$ ßarr1-/-

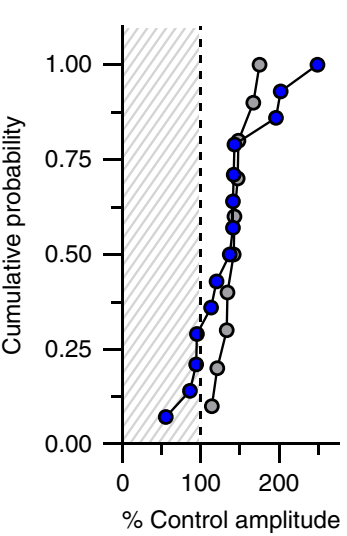

f
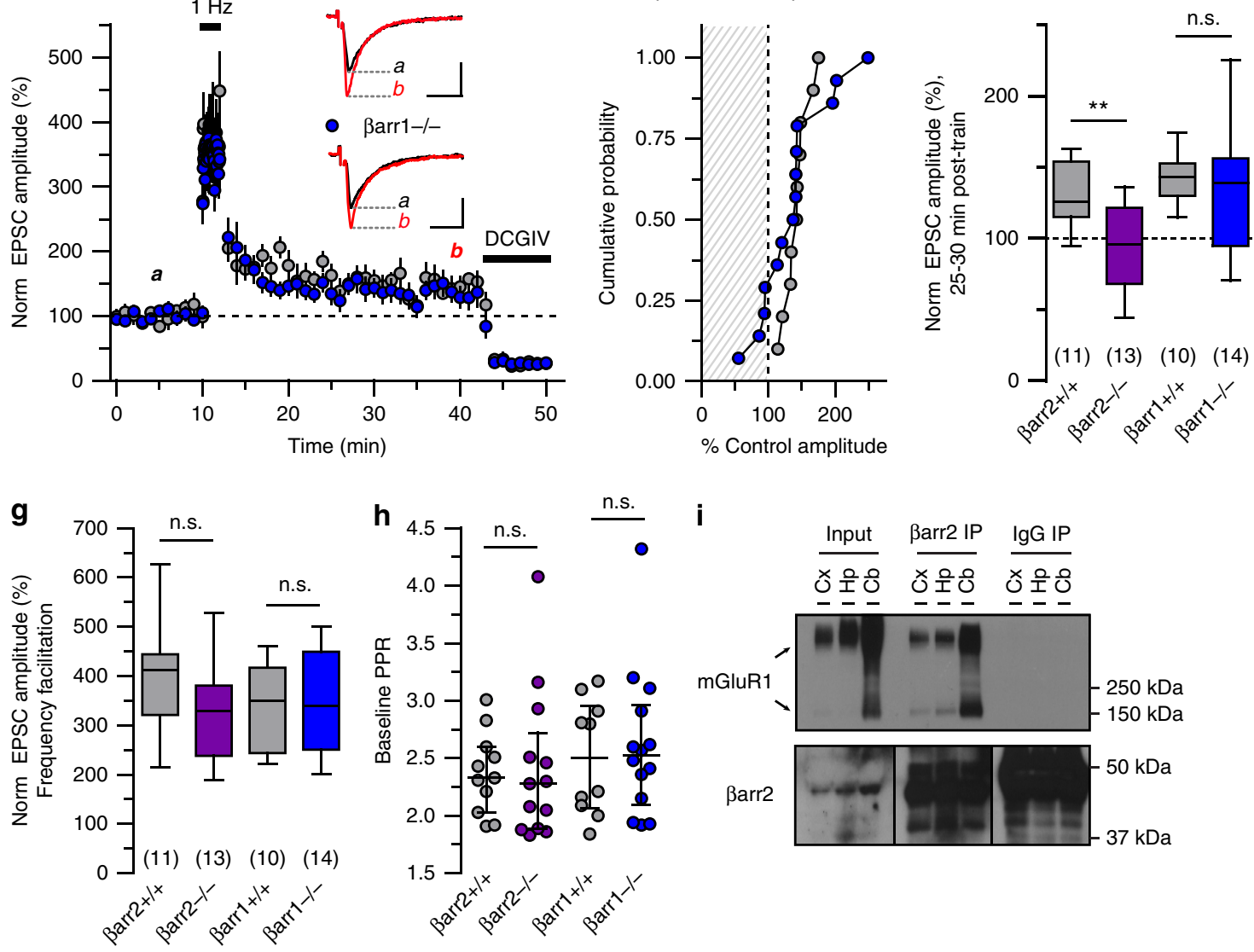

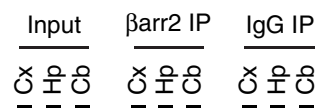

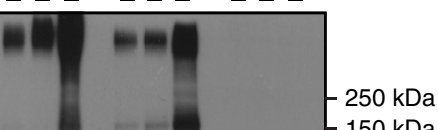

arr2

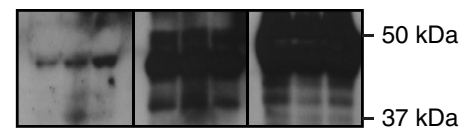

Figure 1 | $\boldsymbol{\beta}$-arrestin2 is required for PP-LFS potentiation of mfEPSCs. (a) Whole-cell voltage clamp recordings in acute hippocampal slices. Paired pulse low-frequency stimulation (PP-LFS) of mossy fibres for 2 min elicits mGluR1-dependent potentiation of mfEPSCs ${ }^{3}$. (b,c) PP-LFS potentiates mfEPSC amplitudes in $\beta$ arr $2^{+/+}$but not $\beta$ arr $2^{-/-}$mice. Mean \pm s.e.m. of pooled, normalized mfEPSCs evoked at basal frequency $(0.05 \mathrm{~Hz})$ and $1 \mathrm{~Hz}$ train frequency are plotted against time. For illustrative purposes, every third mfEPSC is shown. In $\beta$ arr $2^{+/+}$animals $(n=11$ cells, 10 animals), mfEPSC amplitudes measured $25-30$ min post-train were elevated compared with $\beta$ arr $2^{-/}$- post-train mfEPSCs $(n=13$ cells, 12 animals) ( $P=0.009)$. DCG-IV $(1 \mu \mathrm{M})$ inhibited mfEPSCs in both the groups. A cumulative probability histogram shows the post-PP-LFS amplitudes measured from individual experiments. $(\mathbf{d}, \mathbf{e})$ mfEPSCs in $\beta$ arr ${ }^{+/+}(n=10$ cells, seven animals $)$ and $\beta$ arr1 ${ }^{-/-}(n=14$ cells, 11 mice $)$ mice potentiate normally during and following PP-LFS $(P=0.22)$, illustrated by a time course plot of population data and a cumulative probability histogram. (f) A box and 10-90\% whisker plot of pooled posttrain values illustrate normal potentiation of mfEPSCs in $\beta$ arr1 ${ }^{-/-}$, but abolished plasticity in $\beta$ arr $2^{-/-}$slices compared with wild type. (g,h) Frequency facilitation of $\beta$ arr $2^{+/+}$and $\beta$ arr2 ${ }^{-/-}$as well as $\beta$ arr $1^{+/+}$and $\beta$ arr $1^{-/-}$mfEPSCs were not different $(P=0.13, P=0.93$, respectively); baseline PPRs were also not different $(P=0.62, P=0.91$, respectively). Median and interquartile ranges are provided. (i) mGluR1 co-immunoprecipitates with $\beta$ arr2 in wild-type cortex $(\mathrm{Cx})$, hippocampus $(\mathrm{Hp})$ and cerebellum $(\mathrm{Cb})$, but not with an IgG isotype control antibody $(n=3$ replicated observations). Positive $\beta$ arr2 immunoreactivity was observed in immunoprecipitation and lysate preparations loaded into the same gel. Blotting for $\beta$ arr 2 in the rabbit anti-lgG antibody resulted in strong signal $\sim 50-51 \mathrm{kDa}$ during short exposures, consistent with detection of the rabbit lgG heavy chain by the goat anti-rabbit secondary antibody. Representative baseline (black, 'a') and post-train (red, 'b') traces are calibrated as: $x$ axes, 10 ms; $y$ axes, 250 pA. Groups were compared by Mann-Whitney tests. Asterisks denote significance $\left({ }^{\star} P<0.05,{ }^{\star \star} P<0.01\right)$; n.s., non-significant. 
receptor activation ${ }^{7}$, functional linkage between $\mathrm{Src}$ and mGlu1 receptors ${ }^{2,6}$, and genistein sensitivity of PP-LFS-induced plasticity of mfEPSCs $^{3}$. Bath application of PP2 $(20 \mu \mathrm{M})$, a potent and selective antagonist of Src family tyrosine kinases ${ }^{12}$, for $10 \mathrm{~min}$ before and during PP-LFS attenuated potentiation of mfEPSC amplitudes $25-30 \mathrm{~min}$ after the train (111 $\pm 7 \%$ relative to amplitudes measured 5-10 min after drug wash-in, $n=11$ ), whereas mfEPSCs recorded in vehicle (0.2\% dimethylsulphoxide)treated slices remained elevated $(150 \pm 11 \%$ relative to vehicle baseline, $n=8 ; P=0.012$, Fig. $2 \mathrm{a}-\mathrm{c}$ ). To resolve the pre- or post-synaptic localization of Src activated by the PP-LFS stimulus, the experiments were repeated with a peptide inhibitor of c-Src (pp60 cSrc 521-533, phosphorylated at F527, 200 $\mu \mathrm{M}$ ) in the internal pipette solution. PP-LFS stimulation failed to potentiate mfEPSCs in the presence of the Src inhibitor $(107 \pm 3 \%, n=7)$ compared with the control internal recording solution (156 $\pm 13 \%$, $n=7 ; P=0.004$, Fig. $2 \mathrm{~d}-\mathrm{f}$ ), isolating the actions of Src to the post-synaptic CA3 neuron.

The ERK module of the MAPK cascade has also been implicated downstream of group I mGlu receptors, and evidence suggests that mGluR1- $\beta$ arr1 signalling promotes ERK phosphorylation in cell lines ${ }^{13,14}$. We tested the role of ERK and its upstream kinase MEK using bath application of the selective, non-competitive MEK1/2 antagonist u0126 $(20 \mu \mathrm{M})$. Application of $\mathrm{u} 012610 \mathrm{~min}$ before and throughout PP-LFS prevented induction of mGluR1-mediated plasticity of mf-CA3 synapses; antagonist-treated slices exhibited post-train mfEPSC amplitudes that were $97 \pm 8 \%$ of drug baseline $(n=8$; compared with $134 \pm 11 \%$ of baseline for vehicle, $n=8 ; P=0.010$, Fig. $2 \mathrm{~g}-\mathrm{i}$ ).

c-Raf kinase facilitates activation of MAPK/ERK via association with $\beta$ arr2 in cell lines ${ }^{15}$ and, therefore, might have a role in synaptic plasticity mediated by mGlul receptors. We tested this hypothesis by bath applying GW5074 $(1 \mu \mathrm{M})$, a potent inhibitor of c-Raf and b-Raf kinases, 10 min before and during PP-LFS ${ }^{12}$. This compound did not affect potentiation (mfEPSC amplitudes $137 \pm 20 \%$ relative to drug baseline, $n=9$, compared with $135 \pm 12 \%$ of baseline for vehicle, $n=18, P=0.54$ ) (Fig. 2 j-l). This was a surprising result given that the preceding u0126 data clearly support a role for MEK. While canonical models of MAPK signalling cascade proceed through sequential activation of Ras, Raf, MEK and ERK, MEK activation through Raf-independent mechanisms, such as mixed-lineage kinases, phosphoinositidedependent protein kinase- 1 and protein kinase A, has described in non-neuronal cells ${ }^{16-18}$. Our data are also consistent with unconventional activation of MEK as a critical signalling component for induction of PP-LFS-induced plasticity of mossy fibre-CA3 synapses.

LTP of mossy fibre-CA3 synapses does not require $\beta$-arrestins. Classical long-term potentiation of hippocampal mossy fibre-CA3 synapses (mfLTP) is not dependent on group I mGluRs ${ }^{19}$, therefore, we predicted this form of plasticity would be normal in Barr $2^{-I}-$ mice. We tested this prediction by evoking mfLTP with three $1 \mathrm{~s}$ trains of $100 \mathrm{~Hz}$ stimulation, a standard highfrequency stimulation (HFS) paradigm, in CA3 neurons from $\beta a r r 1^{-l}-, \beta a r r 2^{-l}-$, and wild-type littermate control mice. The mean levels of potentiation measured $25-30 \mathrm{~min}$ post-tetanus were equivalent between $\beta$ arr $2^{+1+}$ and $\beta$ arr2 $2^{-7-}$ animals $\left(167 \pm 14 \%\right.$ relative to baseline for $\beta$ arr $2^{+/}+, n=6 ; 165 \pm 36 \%$ relative to baseline for $\beta$ arr $2^{-1}-$ mice, $n=8 ; P=1.0$, Fig. 3a,b,e). Potentiation in $\beta$ arr $1^{-I-}$ mice also was equivalent to wild-type littermates ( $163 \pm 16 \%$ relative to baseline for $\beta a r r 1^{+/+}, n=7$; $190 \pm 23 \%$ relative to baseline for $\beta$ arr $1^{-1-}$ animals, $n=9$, $P=0.56$, Fig. $3 c-e)$. Pre-train PPRs measured in $\beta$ arr 1 and $\beta$ arr2 knockout recordings again were indistinguishable from those obtained from wild-type littermates $\left(2.2 \pm 0.1\right.$ for $\beta$ arr2 ${ }^{+1+}$, $n=6,2.3 \pm 0.2$ for $\beta$ arr2 ${ }^{-l-}, n=8, P=0.65 ; 2.4 \pm 0.2$ for $\beta_{\text {arr }}{ }^{+l+}, n=7,2.3 \pm 0.1$ for $\beta$ arr $\left.1^{-l-}, n=9, P=0.63\right)$. These data demonstrate that robust potentiation of mfEPSCs by HFS is unaffected by the absence of $\beta$ arr1 or $\beta$ arr2.

Non-synaptic mGlu1 activity and $\beta$-arrestin 2 signalling. We next tested the contribution of $\beta$-arrestin 2 to mGluR1-dependent modulation of spiking characteristics in CA3 pyramidal neurons. Pharmacological activation of mGlul receptors persistently suppresses fast after-depolarizing potentials (ADP) through an unknown mechanism that is insensitive to Kv7 channel inhibition and buffering of intracellular calcium ${ }^{20}$. Postspiking conductances are important determinants of rate and pattern of neuronal burst firing, such that mGluR1-mediated suppression of the ADP effectively reduces the initial frequency of action potential firing during a prolonged suprathreshold current injection. Activation of mGluRs in CA3 neurons can elicit a biphasic, outward current followed by an inward current ${ }^{21}$, and the inward, depolarizing current is supported by a $G$ protein-dependent mechanism ${ }^{11}$. Through these studies we sought to examine a potential role for $\beta$-arrestin 2 in non-synaptic processes mediated by mGlu1 receptors, and to concurrently determine whether mGlul receptors are present and functional on the plasma membrane of CA3 pyramidal neurons in $\beta$ arr $2^{-1}-$ mice.

The impact of $\beta$ arr2 on spike frequency was tested by eliciting a train of action potentials with a $500 \mathrm{~ms}$ somatic current injection before and after (S)-3,5-dihydroxyphenylglycine (DHPG) application $(50 \mu \mathrm{M}, 5 \mathrm{~min})$ in the presence of mGluR5 antagonist 3-((2-methyl-4-thiazolyl)ethynyl)pyridine (MTEP, $1 \mu \mathrm{M})$ and $\alpha$-amino-3-hydroxy-5-methyl-4-isoxazolepropionic acid (AMPA)/kainate receptor antagonist 6-cyano-7-nitroquinoxaline-2,3-dione (CNQX, $50 \mu \mathrm{M})$. Notably, we did not observe an ADP-dependent burst of action potentials at the beginning of the current injection as was observed previously ${ }^{20}$, which could be due to a difference in species, recording temperature, or other experimental parameters. CA3 neurons in $\beta$ arr $2^{+I+}$ animals exhibited a significant reduction in instantaneous frequency for the first two action potentials elicited after mGluR1 activation $(18.1 \pm 1.6 \mathrm{~Hz}$ pre-DHPG, $12.0 \pm 1.2 \mathrm{~Hz}$ with DHPG, $n=17$; $P=0.0003$, Fig. 4a). A marked reduction also was observed in parallel experiments using $\beta$ arr $2^{-l-}$ littermates $(16.6 \pm 0.8 \mathrm{~Hz}$ pre-DHPG, $\quad 12.6 \pm 1.1 \mathrm{~Hz}$ with DHPG, $n=14 ; \quad P=0.0023$, Fig. $4 \mathrm{~b})$; the reduction in $\beta$ arr $2^{+I+}$ and $\beta$ arr $2^{-l-}$ recordings was not different $\left(-33.6 \pm 4.3 \%\right.$ for $\beta$ arr $2^{+l+}, \quad n=17$; $-24.0 \pm 5.6 \%$ for $\beta$ arr $\left.2^{-I-}, n=14 ; P=0.23\right)$. These results indicate that pharmacological activation of mGlul receptors causes slowing of action potential firing in CA3 neurons through a $\beta$ arr2-independent mechanism.

We also monitored membrane potential during DHPG application. Consistent with observations in dissociated CA3 neurons ${ }^{21}$, we observed a membrane hyperpolarization in CA3 neurons in slice recordings from $\beta$ arr2 ${ }^{+1+}$ mice $(-70.4 \pm 0.5 \mathrm{mV}$ pre-DHPG, $-77.5 \pm 0.9 \mathrm{mV}$ with DHPG, $n=17, P=0.0005$, representative trace in Fig. $4 \mathrm{~d})$. In 7 of 17 cells, hyperpolarization was followed by a membrane depolarization that exceeded the baseline membrane potential and led to spiking (Fig. 4d); among the cells in which this depolarization was not sufficient to evoke spiking, we observed depolarization above baseline within $5 \mathrm{~min}$ of DHPG application $(-70.9 \pm 0.7 \mathrm{mV}$ pre-DHPG, $-65.9 \pm 1.0 \mathrm{mV}$ with DHPG, $n=10, P=0.006$, representative trace in Fig. $4 \mathrm{f})$. DHPG application also produced the initial hyperpolarizing potential in $\beta$ arr $2^{-I-}$ recordings $(-71.1 \pm 0.7 \mathrm{mV}$ pre-DHPG, 

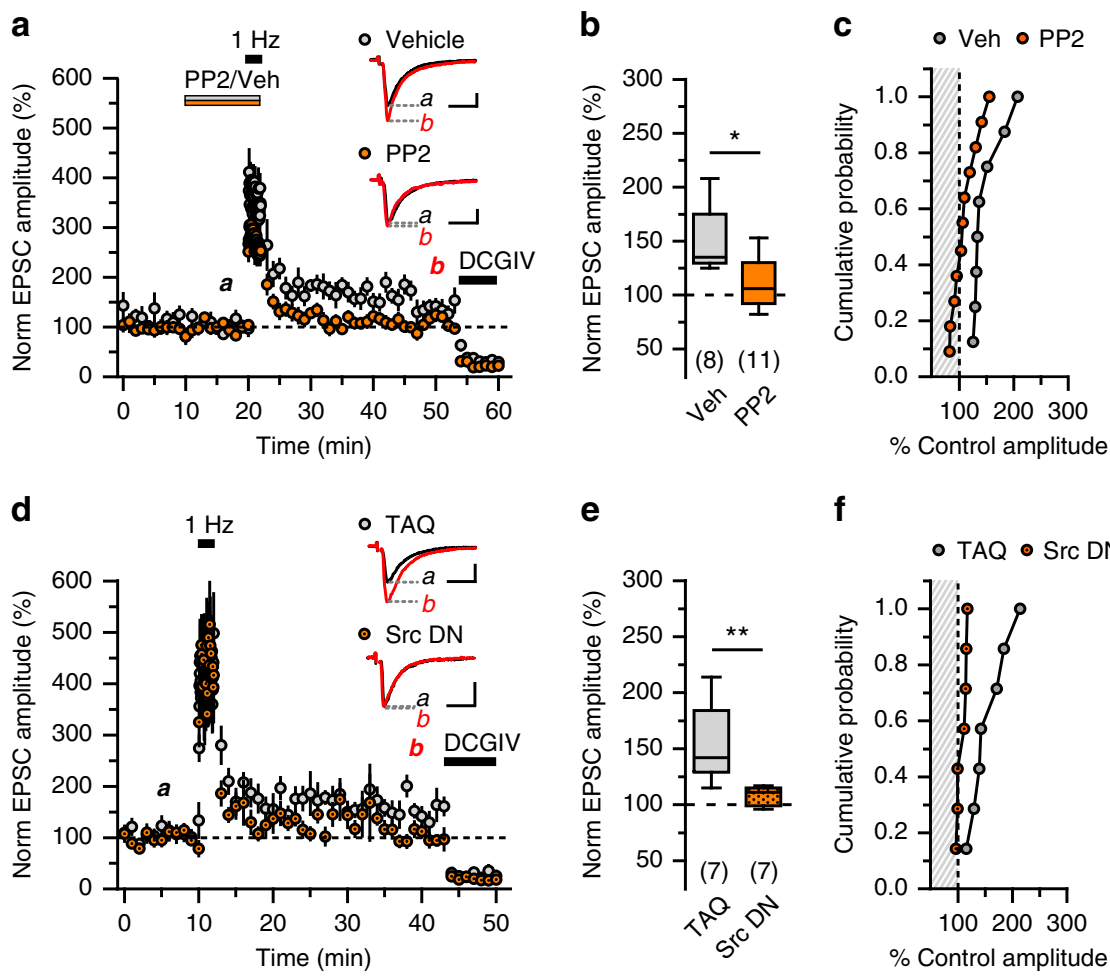

f
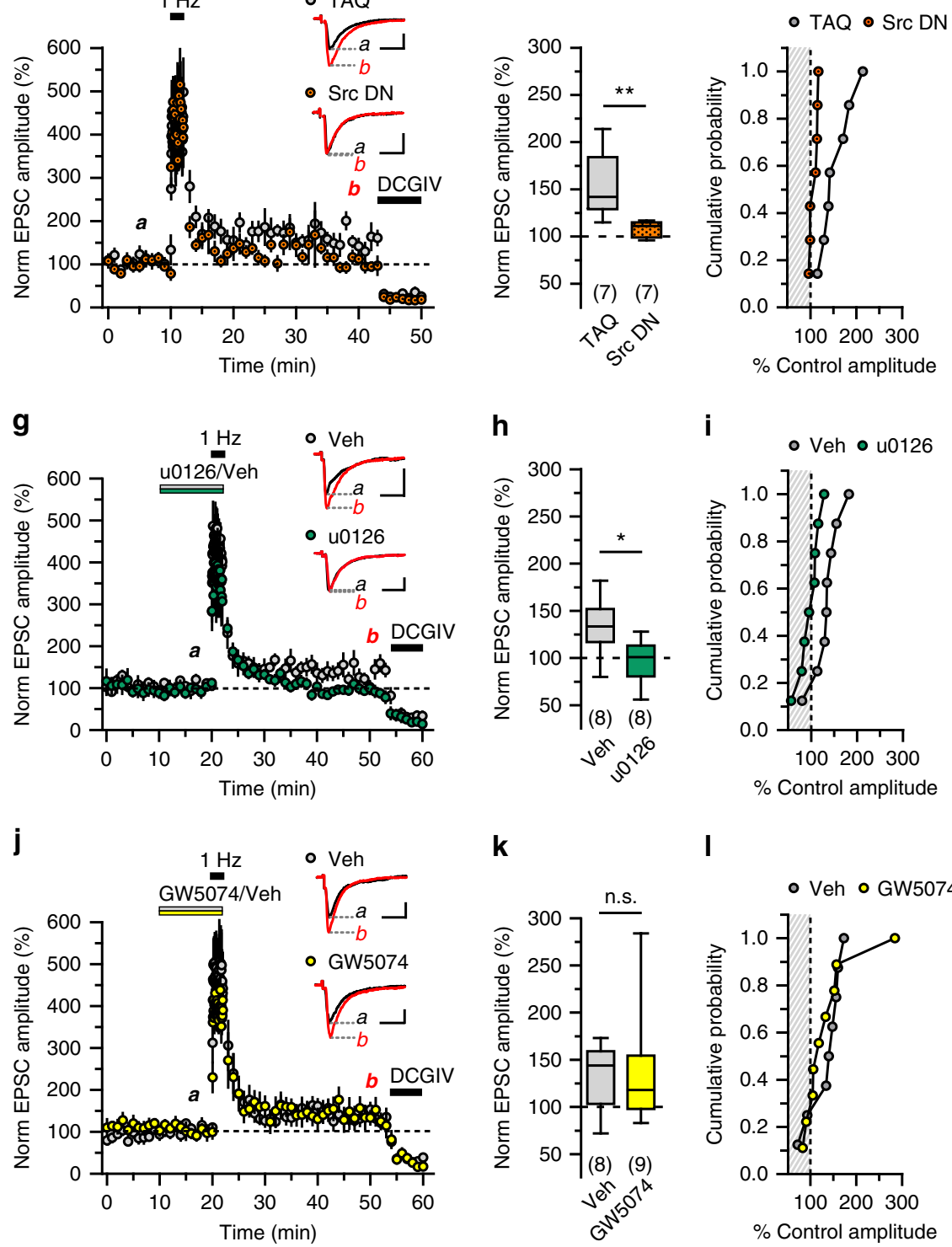

I

Figure 2 | Kinases involved in potentiation of mfEPSCs. (a-c) Src-family tyrosine kinase antagonist PP2 attenuates potentiation of mfEPSCs by PP-LFS. Either $0.2 \%$ dimethylsulphoxide (Vehicle/Veh) or PP2 $(20 \mu \mathrm{M})$ was applied before and during the train $(P=0.012, n=11$ PP2-treated cells and eight vehicle cells from 14 animals). A cumulative probability histogram and 10-90\% box plot summarize the population data for post-train mfEPSC amplitudes. (d-f) pp60c-Src 521-533, a peptide inhibitor of Src, also attenuates potentiation of mfEPSCs by PP-LFS when provided in the recording microelectrode $(P=0.004, n=7$ cells using TAQ internal from six animals, $n=7$ cells from seven animals with pp60c-Src). (g-i) MEK1/2 antagonist u0126 (20 $\mu \mathrm{M})$ prevents potentiation of mfEPSCs by PP-LFS ( $P=0.010, n=8$ cells treated with $u 0126$ and $n=8$ vehicle-treated cells from 13 total animals). (j-I) b-Raf 1 and c-Raf 1 antagonist GW5074 $(1 \mu \mathrm{M})$ has no effect on plasticity induced by PP-LFS, compared with a vehicle control $(P=0.54, n=9$ cells treated with GW5074, $n=8$ vehicle-treated cells from 15 total animals). Calibration of representative traces: $x$ axes, 10 ms; $y$ axes, 250 pA. Groups were compared by Mann-Whitney tests. Asterisks denote significant differences between treatment groups $\left({ }^{\star} P<0.05,{ }^{\star \star} P<0.01\right)$; n.s., non-significant. 


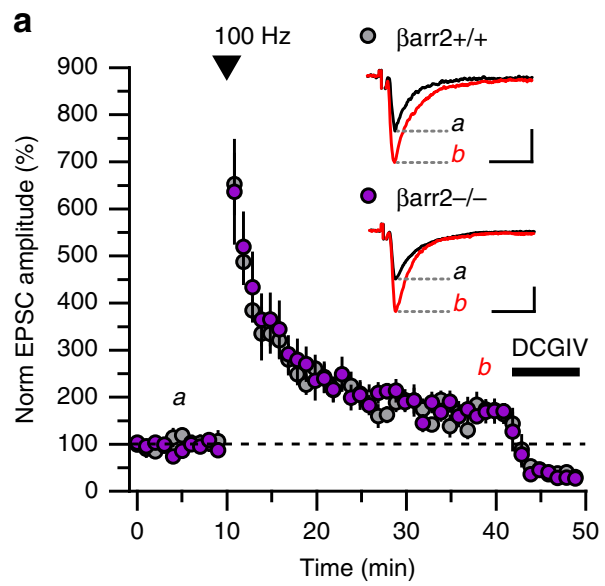

b
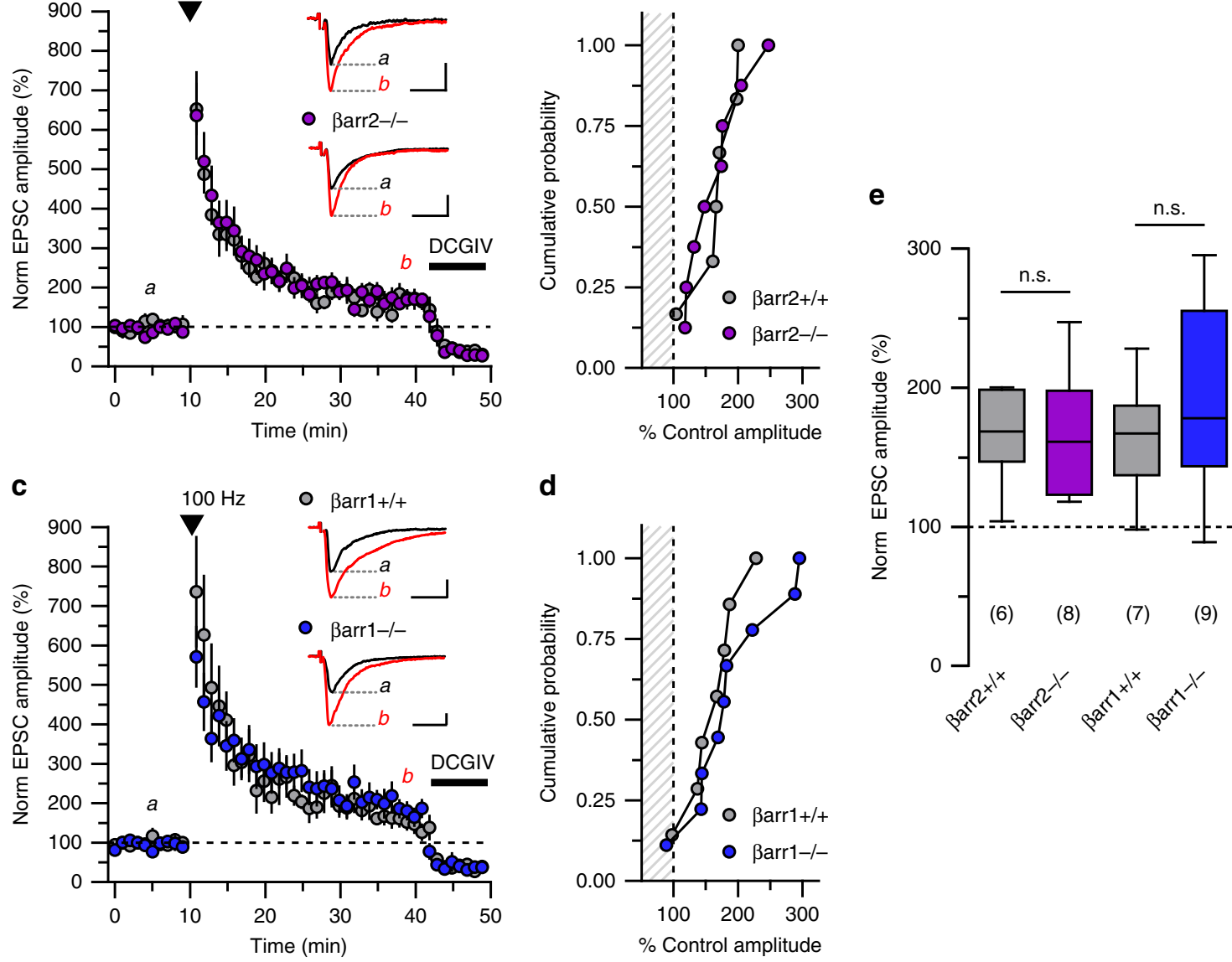

d

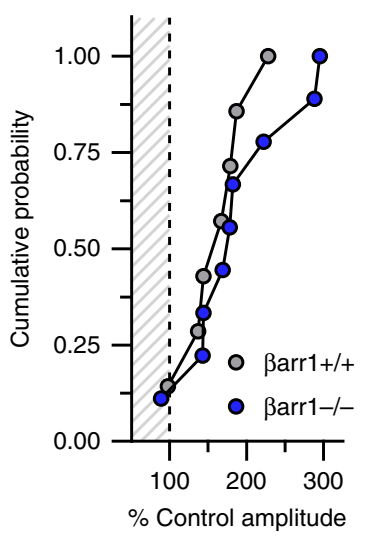

)

Figure 3 | Classical mossy fibre LTP does not require $\boldsymbol{\beta}$-arrestins. (a,b) High-frequency stimulation (HFS) of mossy fibre inputs elicits robust potentiation of mfEPSCs in slice recordings from both $\beta$ arr $2^{-/-}$and $\beta$ arr $2^{+/+}$mice $(P=0.85, n=6$ cells from three wild-type animals, $n=8$ cells from five knockout animals). A time course plot and cumulative probability histogram illustrate robust facilitation following HFS (amplitudes during HFS were omitted). Amplitudes deprecate over time but remain elevated relative to baseline $25-30$ min post-tetanus. (c,d) mfLTP is intact in $\beta$ arr $1^{-/}-$mice. mfEPSC amplitudes measured from $\beta a r r 1^{+/+}$and $\beta a r r 1^{-/-}$mice are strongly potentiated immediately following tetanus and slowly deprecate to similar levels above baseline 30 min later ( $P=0.56, n=7$ cells from six wild-type animals, $n=9$ cells from eight knockout animals). Individual post-train measurements are provided in a cumulative probability histogram. (e) mfLTP potentiation levels in $\beta$-arrestin knockout mice and wild-type littermates are summarized by a box plot and 10-90th percentile whiskers. Representative trace calibration: $x$ axes, 10 ms; $y$ axes, 250 pA. Groups were compared by Mann-Whitney tests; n.s., non-significant.

$-78.9 \pm 1.7 \mathrm{mV}$ with DHPG, $n=14, P=0.0023$, representative trace in Fig. 4d). Barr2 ${ }^{+I+}$ and $\beta$ arr2 $2^{-l-}$ mice responded to DHPG application with hyperpolarizations of equal magnitude $\left(7.1 \pm 1.1 \mathrm{mV}\right.$ in wild type, $n=17 ; 7.8 \pm 2.0 \mathrm{mV}$ in $\beta$ arr2 ${ }^{-/-}$, $n=14, P=0.62$, Fig. $4 c)$. In $\beta$ arr $2^{-I}$ CA3 pyramidal neurons, DHPG elicited spiking in 7 of 14 cells (Fig. 4d), but the nonspiking cells exhibited no appreciable depolarization above baseline membrane potential within five min of DHPG application $(-70.5 \pm 0.3 \mathrm{mV}$ pre-DHPG, $-68.3 \pm 1.5 \mathrm{mV}$ with DHPG, $n=7, \quad P=0.22$, representative trace in Fig. $4 \mathrm{f})$. The peak depolarization in membrane potential from baseline measured 3-5 min after DHPG application was, therefore, different between

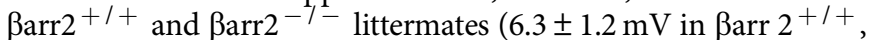
$n=13 ; 2.2 \pm 1.4 \mathrm{mV}$ in $\beta$ arr2 ${ }^{-l}-, n=7, P=0.047$, Fig. $\left.4 \mathrm{e}\right)$. Thus, $\beta$ arr2-dependent signalling pathways are but a subset of those that can modulate intrinsic conductances in CA3 neurons. These experiments also confirmed that mGlul receptors are present and functional on the plasma membrane in $\beta$ arr $2^{-/}$mice.

Barr2 mediates PP-LFS, mGluR-LTD of CA1 synapses. Activation of group I mGluRs induces LTD at hippocampal Schaffer collateral-CA1 (Sch-CA1) synapses. This form of plasticity is induced by a long train of paired stimuli delivered at a low frequency (PP-LFS LTD) ${ }^{22,23}$ or pharmacological activation by group I mGluR agonist DHPG (DHPG LTD) $22,24,25$, and is thought to require MAPK/ERK ${ }^{26}, \mathrm{JNK}^{27}$ and developmentally regulated rapid protein synthesis ${ }^{22,28}$. Synaptic modification by PP-LFS is induced by co-existing NMDA receptor-independent (for example, mGluR-dependent) and NMDA receptordependent mechanisms ${ }^{29}$. We inhibited NMDA receptors in order to test the role of $\beta$-arrestins in mGluR-dependent PP-LFS LTD in comparison studies using P16-P25 $\beta$ arr knockout mice.

Paired, low-frequency stimulation of Schaffer collateral inputs for 15 min (Fig. 5a) elicits depression of EPSC amplitudes of CA1 neurons in $\beta$ arr $2^{+} l+$ mice measured $25-30$ min after the train (70 $\pm 6 \%$ compared with baseline, $n=24$ ). In contrast, LTD was absent in recordings from $\beta$ arr $2^{-I-}$ mice $(94 \pm 10 \%$ compared with baseline, $n=17, P=0.03$, Fig. 5b,c,f). PP-LFS induced equivalent levels of LTD in $\beta$ arr1 $1^{+}+$and $\beta$ arr $1^{-1-}$ mice $\left(78 \pm 8 \%\right.$ compared with baseline in $\beta$ arr $1^{+/+}, n=17 ; 70 \pm 8 \%$ in $\beta$ arr $1^{-I}, n=12, P=0.39$, Fig. $\left.5 \mathrm{~d}-\mathrm{f}\right)$. Baseline paired pulse facilitation was not different when comparing $\beta$ arr $2^{-1-}$ and Barr $1^{-I}-$ mice with wild-type littermate groups $(1.45 \pm 0.05$ for $\beta a r r 2^{+I+}, n=24 ; 1.38 \pm 0.07$ for $\beta$ arr $2^{-I}, n=17, P=0.46$; 
a Initial spike frequency ßarr2+/+

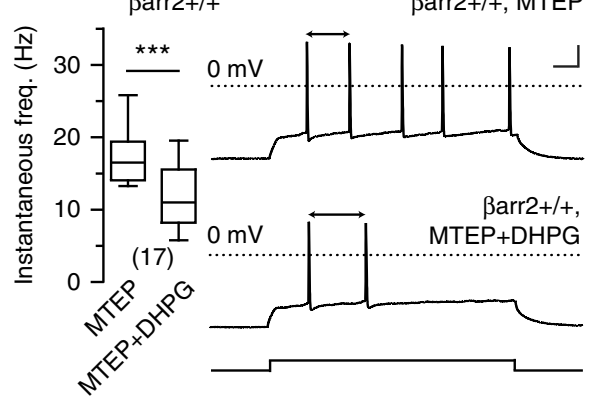

C
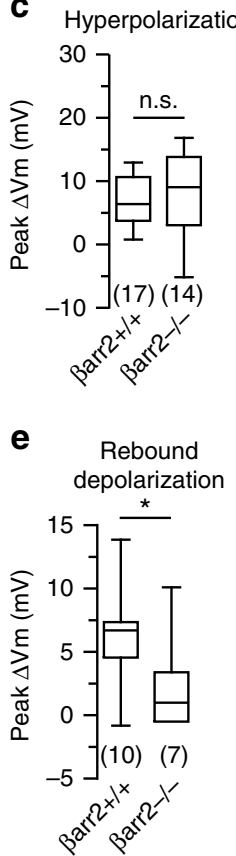

d

ßarr2+/+, MTEP, Spiking cell $(7 / 17)$
DHPG

f

ßarr2+/+, MTEP, Non-spiking cell (10/17) b Initial spike frequency ßarr2-I-

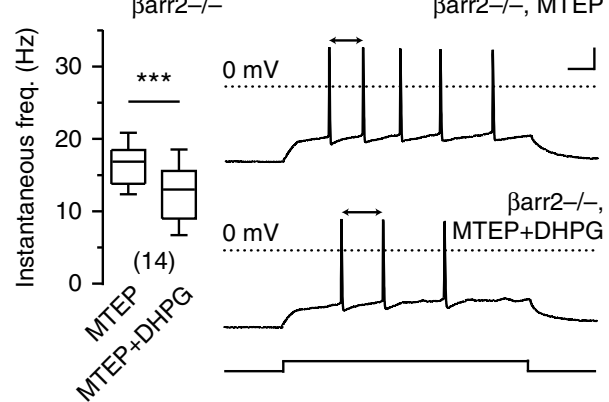

ßarr2-/-, MTEP, Spiking cell $(7 / 14)$
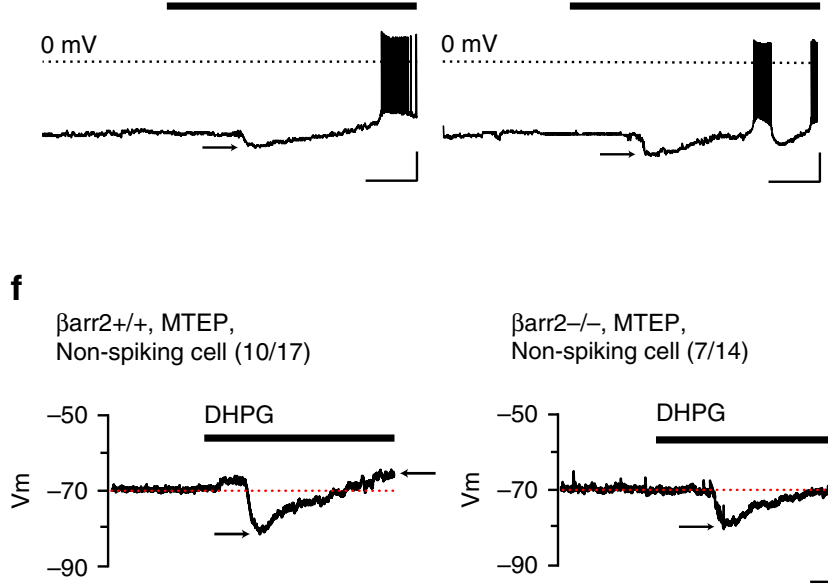

Non-spiking cell $(7 / 14)$

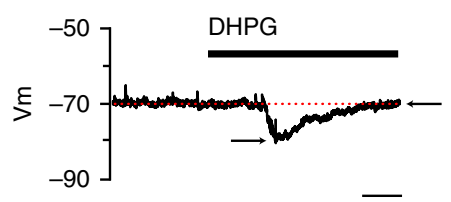

Figure 4 | Cell-intrinsic activities differentially require $\boldsymbol{\beta}$-arrestin2. (a) After DHPG $(50 \mu \mathrm{M})$ application, the instantaneous frequency of the first two action potentials elicited during a 500 ms suprathreshold current step is reduced in $\beta$ arr $2^{+/+}$recordings $(P=0.0003, n=17$ cells from nine mice). Action potentials were evoked in CA3 neurons in the presence of mGluR5 antagonist MTEP $(1 \mu \mathrm{M})$ and AMPA/kainate receptor antagonist CNQX $(50 \mu M)$. Instantaneous frequency measured during vehicle (MTEP) and DHPG application (MTEP + DHPG) are summarized in a box plot. Representative $\beta$ arr2 $+/+$ traces before and after DHPG application are shown with double-headed arrows denoting the intervals used to calculate instantaneous frequency. (b) In $\beta$ arr $2^{-/}$- recordings, DHPG activation of mGlu1 receptors reduces the instantaneous frequency of action potential firing during a $500 \mathrm{~ms}$ current step $(P=0.0023, n=14$ cells from seven animals). Vehicle (MTEP) and DHPG (MTEP + DHPG) instantaneous frequencies are summarized in a box plot. Representative traces from a $\beta$ arr $2^{-/}$- CA3 pyramidal neuron show action potentials evoked by suprathreshold current injection under vehicle and DHPG conditions. (c) Hyperpolarization among spiking and non-spiking cells elicited during DHPG application is normal in $\beta$ arr $2^{-/}$mice $(P=0.62)$, as shown in a box plot. (d) Barr2 ${ }^{+/+}$and $\beta$ arr $2^{-/-}$CA3 neurons exposed to DHPG (black bar) exhibited a brief hyperpolarizing potential. Representative traces of spiking cells are provided, and black arrows denote the peak hyperpolarization. (e) A subset of $\beta$ arr $2^{+/+}$CA 3 neurons exhibit a rebound depolarization with prolonged application of DHPG that did not lead to spiking, but in $\beta$ arr $2^{-/}$- CA3 non-spiking neurons, the rebound depolarization is reduced or absent $(P=0.047)$. Rebound depolarization measured in only the non-spiking population of cells is shown in a box plot. (f) Representative traces from non-spiking $\beta$ arr2 ${ }^{+/+}$and $\beta$ arr2 $2^{-/-}$CA3 neurons are provided. Black arrows denote peak hyperpolarization and subsequent rebound depolarization. Current step trace calibration: $x$ axes, 50 ms; $y$ axes, 20 mV, 600 pA. Membrane voltage traces are calibrated as: $x$ axes, 1 min; $y$ axes, $25 \mathrm{mV}$. Instantaneous frequencies altered by DHPG within genotypes were compared by Wilcoxon tests; hyperpolarization and rebound depolarizations compared between genotypes were analysed by Mann-Whitney tests. Asterisks denote significance $\left({ }^{\star} P<0.05\right.$, $\left.{ }^{\star \star \star} P<0.001\right)$; n.s., non-significant.

$1.47 \pm 0.05$ for $\beta \operatorname{arr} 1^{+/+}, n=17 ; 1.56 \pm 0.11$ for $\beta a r r 1^{-/-}$, $n=12, \quad P=0.56$, Fig. $5 \mathrm{~g})$. These results indicate that mGluR-dependent depression of synaptic transmission in CA1 pyramidal neurons is also dependent on $\beta$ arr2.

Sch-CA1 PP-LFS LTD requires mGluR5. We next conducted similar experiments with the addition of mGluR1 and mGluR5 antagonists in the $\beta$-arrestin 2 gene-targeted mice to delineate the induction mechanism of PP-LFS-induced LTD at Sch-CA1 synapses. MTEP, a negative allosteric modulator for mGlu5 receptors ${ }^{30}$, was bath applied to acute slice preparations $10 \mathrm{~min}$ before and throughout the $15 \mathrm{~min}$ PP-LFS train; mGluR5 antagonism by MTEP prevented induction of LTD and resulted in equal recovery of EPSC amplitudes measured 25-30 min post-train in $\beta$ arr $2^{+1+}$ and $\beta$ arr $2^{-1-}$ mice $(86 \pm 4 \%$ in wild type, $n=14 ; 96 \pm 5 \%$ in knockout, $n=19 ; P=0.27$, Fig. 6a,b,g). To test for contributions by mGluR1, the competitive mGluR1 
a

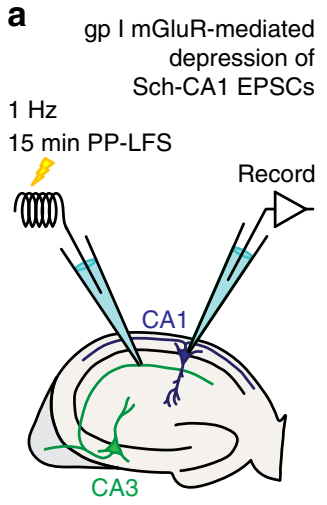

b

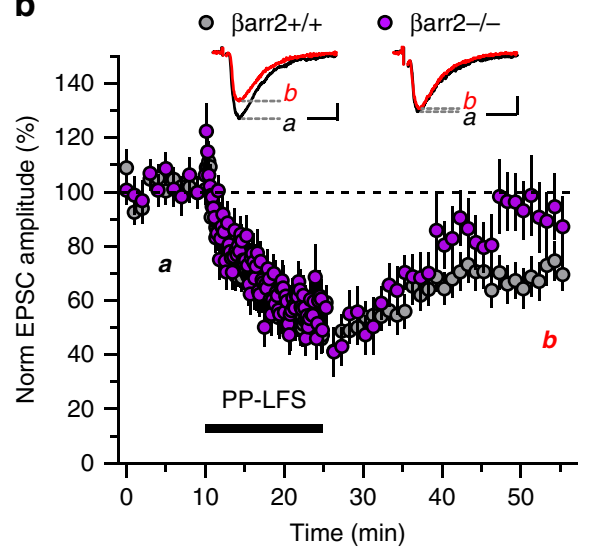

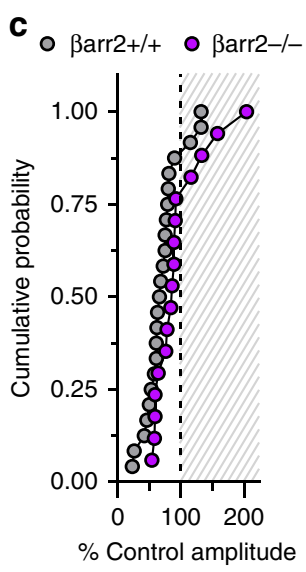

d

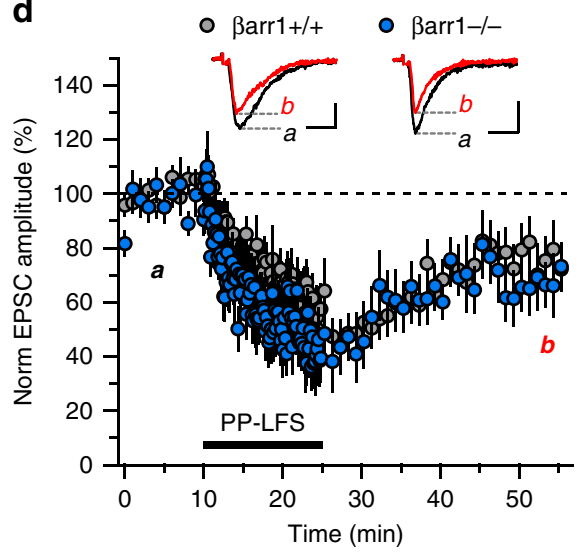

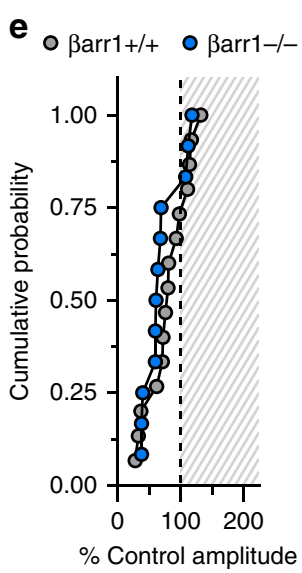

f

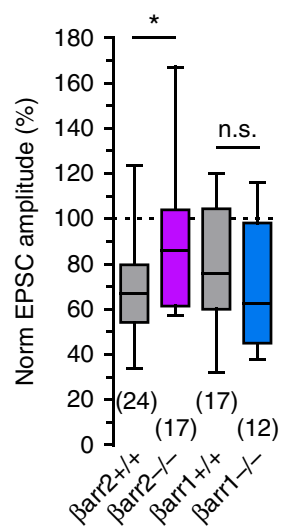

g

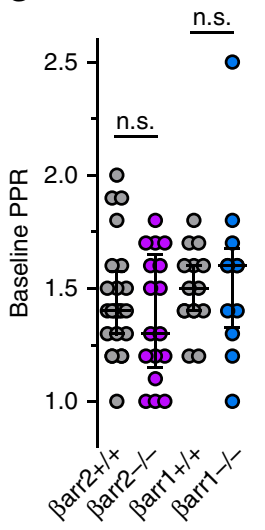

Figure $\mathbf{5}$ | Deficits in CA1 $\mathbf{~ m G l u R - L T D ~ i n ~} \boldsymbol{\beta}$-arrestin2 $\mathbf{~}^{-/-}$neurons. (a) Whole-cell voltage-clamp recordings in acute hippocampal CA1 slice recordings. Schaffer collaterals in the stratum radiatum received PP-LFS for $15 \mathrm{~min}$, which depresses EPSC amplitudes recorded in CA1 pyramidal neurons. (b,c) Group I mGluR-mediated depression of Sch-CA1 synaptic transmission is impaired in $\beta$ arr $2^{-/-}$mice. A time course plot shows persistent depression of EPSC amplitudes 30 min after PP-LFS in $\beta a r r 2+/+$ mice $(n=24$ cells from 17 animals). In contrast, Sch-CA1 EPSCs from $\beta$ arr $2-/-$ animals recover more than wild types 25-30 min after PP-LFS ( $P=0.03, n=17$ cells from 10 animals). For illustrative purposes, every third event was plotted during basal stimulation, and every ninth event was plotted during $1 \mathrm{~Hz}$ PP-LFS. A cumulative probability histogram illustrates separation of post-PP-LFS amplitudes between $\beta$ arr $2+/+$ and $\beta$ arr $2^{-/}-$recordings. (d,e) PP-LFS induces equivalent depression of Sch-CA1 EPSCs in $\beta$ arr $1^{-/-}$and $\beta$ arr $1^{+/}+(P=0.39, n=12$ cells from seven wild-type animals, $n=17$ cells from 10 Barr1 ${ }^{-/}$- mice), shown in time course and cumulative probability histograms. (f) Summary box plot of PP-LFS LTD post-train amplitudes from $\beta$ arr2 and $\beta$ arr1 groups. ( $\mathbf{g})$ Baseline PPRs measured using $\beta$ arr2- and $\beta$ arr1-null mice were not different from wild-type littermates $(P=0.46$

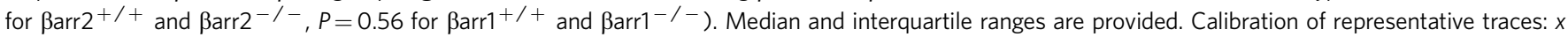
axes, $10 \mathrm{~ms}$; $y$ axes, 100 pA. Groups were compared by Mann-Whitney tests. Asterisks denote significance ( ${ }^{\star}<0.05$ ); n.s., non-significant.

antagonist LY367385 $(50 \mu \mathrm{M})$ was bath applied before and during PP-LFS ${ }^{31}$. EPSCs from neurons in $\beta$ arr $2^{-/-}$mice again did not exhibit LTD after PP-LFS (91 $\pm 3 \%, n=14)$, whereas those from Barr $2^{+I+}$ animals were depressed $(70 \pm 4 \%, n=10 ; P=0.003$, Fig. $6 c, d, g)$. We, therefore, conclude that PP-LFS induces LTD through activation of mGlu5 receptors, but not mGluR1, and that Barr2 is required to induce this form of plasticity at Sch-CA1 synapses.

Chemical LTD does not require $\boldsymbol{\beta}$-arrestin2. We tested if $\beta$ arr2 is required for the induction of a chemical form of LTD induced by the group I mGluR agonist DHPG; this form of plasticity is thought to share some signalling elements with that induced by electrical stimulation ${ }^{22,26}$. DHPG $(100 \mu \mathrm{M}, 5 \mathrm{~min})$ application to acute hippocampal slices from juvenile (P16-P25) mice reduced Sch-CA1 EPSC amplitudes to $67 \pm 7 \%$ of control in wild-type mice $(n=13)$ and $72 \pm 8 \%$ of control amplitudes in $\beta$ arr $2^{-\Gamma-}$ littermates $(n=8)$, which was not statistically different $(P=0.86$, Fig. $6 \mathrm{e}-\mathrm{g}$ ). Thus, $\beta$ arr2 is not essential to DHPG-induced LTD, in contrast with its role in PP-LFS LTD.
mGlu5 surface expression is not altered in $\beta$ arr $2^{-/-}$mice. Because $\beta$ arr2 has a well-characterized role in internalization of many GPCRs, we evaluated whether mGluR5 surface localization was affected in $\beta$ arr2 gene-targeted mice. We incubated hippocampal wild-type and $\beta$ arr $2^{-}-$brain tissue from acute slice preparations in biotin, and enriched for biotinylated surface membrane proteins using streptavidin Sepharose beads. Western blotting of the biotinylated fraction from wild-type and ßarr $2^{-1}-$ tissue showed equivalent levels of hippocampal, surface-expressed mGluR5 when normalized to kainate receptor subunit GluK2 (108 kDa; representative immunoblotting of three wild-type and $3 \beta$ arr $2^{-l-}$ mice is shown in Fig. 6 h, uncropped blots are provided in Supplementary Fig. 3). GluK2 is a surface and membrane-bound protein not known to associate with $\beta$ arr2 and was, therefore, utilized as a loading control. mGluR5/GluK2 optical density was $0.90 \pm 0.19$ a.u. for wild type, and $0.90 \pm 0.18$ a.u. for Barr $2^{-1}-(n=3$ pairs, $P=1$, Fig. 6h). Notably, mGluR5 and GluK2 immunoreactivity was low in the non-biotinylated fraction compared with the biotinylated fraction, but immunoreactivity for $\beta$-tubulin $(50 \mathrm{kDa})$, an intracellular cytoskeletal protein, was greater in the non-biotinylated fraction than the biotinylated 

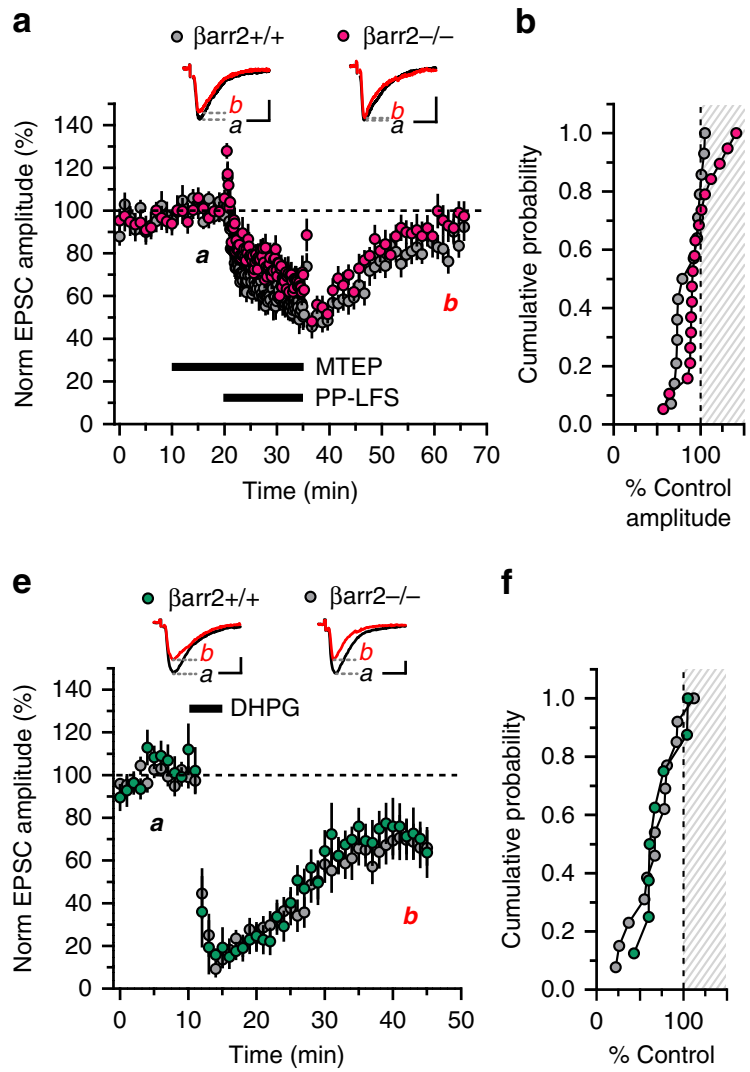

$\mathbf{f}$
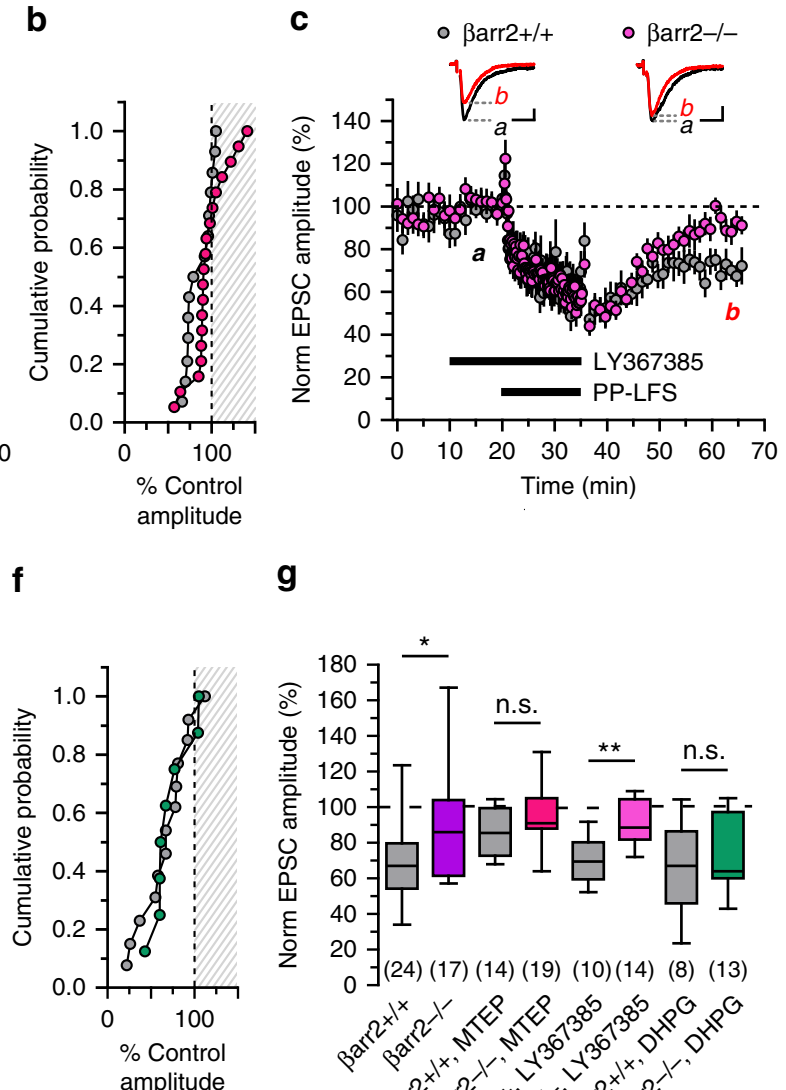

d

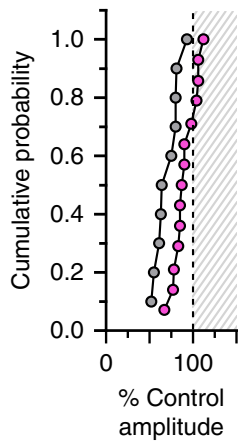

g
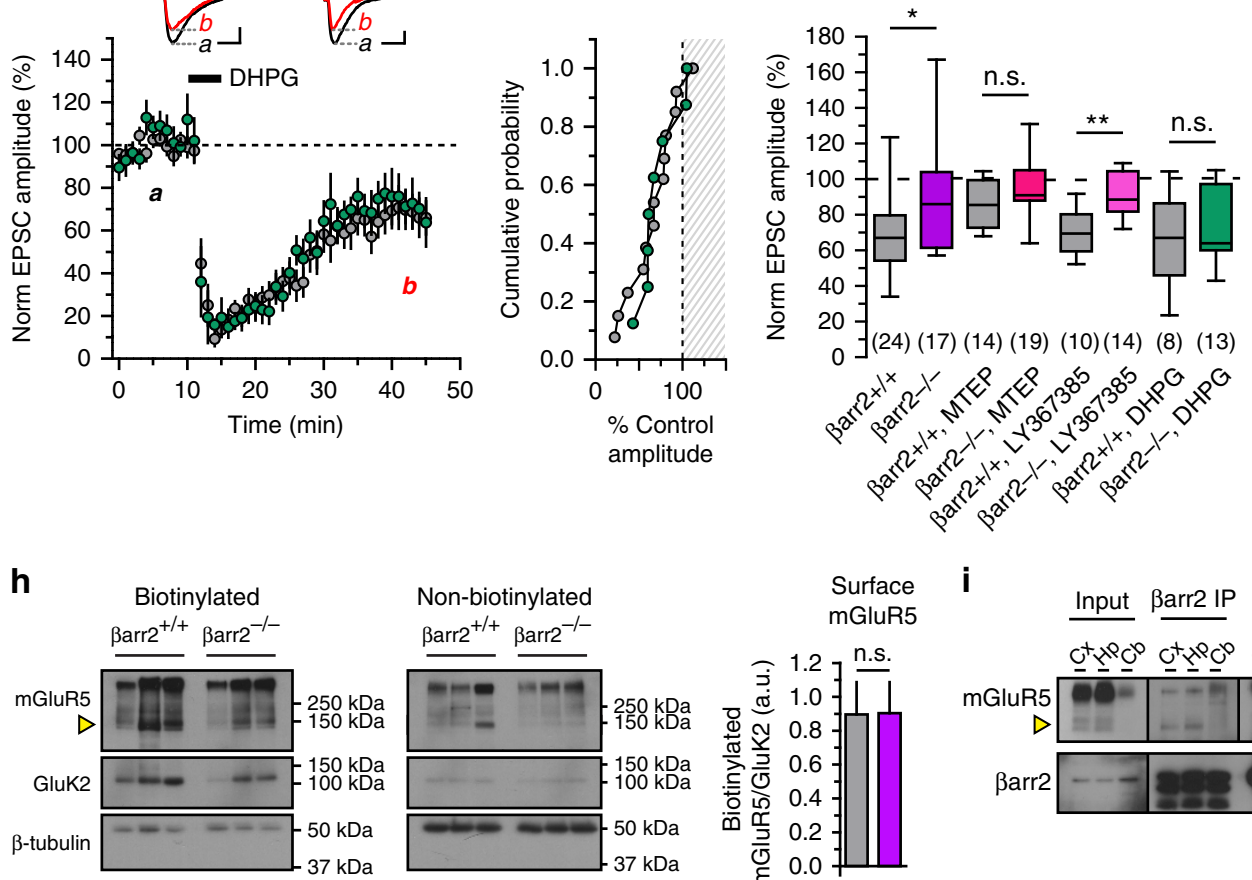

i mGluR5
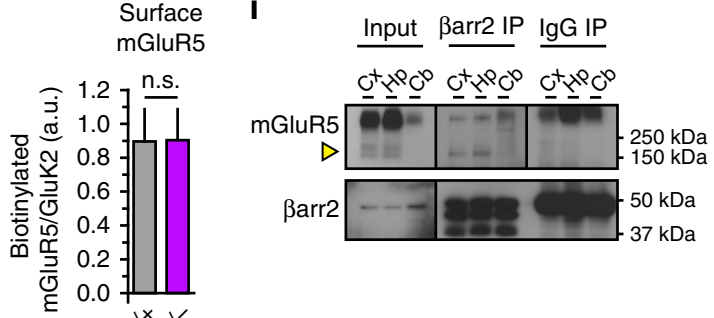

Figure 6 | mGluR5 is necessary for LTD induced by synaptic stimulation. (a,b) Inhibition of mGluR5 by MTEP $(1 \mu \mathrm{M})$ attenuates prolonged Sch-CA1 synaptic depression in $\beta a r r 2^{+/+}$and $\beta$ arr2 $2^{-/-}$mice. A time course plot shows depression of EPSC amplitudes during PP-LFS in the presence of MTEP, but normalized amplitudes in both $\beta$ arr $2^{+/+}$and $\beta$ arr $2^{-/-}$animals recover by 30 min after PP-LFS $\left(P=0.27, n=14\right.$ cells from seven $\beta$ arr $2^{+/+}$mice, $n=19$ cells from 12 Barr2 ${ }^{-/-}$mice). Every third event was plotted during basal stimulation, and every ninth event was plotted during PP-LFS. A cumulative histogram further summarizes post-train data. (c,d) Using LY367385 $(50 \mu \mathrm{M})$, an mGluR1 antagonist, PP-LFS LTD is observed in $\beta$ arr $2^{+/+}$, but not $\beta$ arr2 ${ }^{-/-}$mice. A time course plot illustrates depression of EPSCs in $\beta$ arr2 $+/+$ following PP-LFS in the presence of LY367385 and recovery to baseline levels in Barr2 ${ }^{-/}$animals $\left(P=0.003, n=10\right.$ cells from six $\beta$ arr $2^{+/+}$mice, $n=14$ cells from eight $\beta$ arr $2^{-/}-$mice); data is summarized in a cumulative histogram. $(\mathbf{e}, \mathbf{f})$ DHPG induces LTD in $\beta$ arr $2^{+/+}$and $\beta$ arr $2^{-/-}$mice. $\beta$ arr $2^{+/+}$, and $\beta$ arr $2^{-/-}$recordings have similar time courses for depression and post-train amplitude distributions ( $P=0.86, n=13$ cells from six wild-type mice, $n=8$ cells from four knockout mice). ( $(\mathbf{g})$ A box plot shows recovery of all $\beta$ arr $2^{-/-}$ conditions from PP-LFS LTD but not DHPG LTD; PP-LFS LTD is abrogated in $\beta$ arr2 $+/+$ recordings only by MTEP. (h) Monomeric mGluR5 (yellow arrow) and GluK2 immunoreactivity was detected in both the $\beta a r r 2^{+/+}$and $\beta$ arr $2^{-/-}$surface biotinylated fractions by western blotting, and less so in non-biotinylated fractions ( $n=3$ pairs of $\beta$ arr $2^{+/+}$and $\beta$ arr $2^{-/-}$mice). $\beta$-tubulin immunoreactivity indicated that intracellular proteins were enriched in the non-biotinylated fraction. Quantitated monomeric mGluR5 optical density normalized against the GluK2 signal is provided in a bar graph illustrating the mean and s.e.m.

(i) mGluR5 co-immunoprecipitates with $\beta$-arrestin2 in the cortex and hippocampus of wild-type mouse brains ( $n=5$ blots). Pull-down by an lgG isotype antibody yields little $\mathrm{mGlu} 5$ receptor immunoreactivity. $\beta$-arrestin 2 is strongly detected in the immunoprecipitation and input conditions. Representative traces calibration: $x$ axes, $10 \mathrm{~ms} ; y$ axes, 100 pA. Groups were compared by Mann-Whitney tests. Asterisks denote significance $\left({ }^{\star} P<0.05\right.$, $\left.{ }^{\star \star} P<0.01\right) ;$ n.s., non-significant.

fraction. These results indicate that streptavidin immunoprecipitation was strongly enriched for biotinylated membrane proteins and that mGluR5 expression is unaltered in $\beta$ arr $2^{-1}$ mice. Expression of mGluR5 in total and membrane-enriched fractions also is not grossly affected in ßarr2 knockout animals (Supplementary Fig. 4), and thus it is unlikely that the deficit in PP-LFS LTD in $\beta$ arr2 $2^{-1-}$ mice can be attributed to loss of surface-expressed mGluR5. 
mGlu5 receptors and $\beta$-arrestin 2 associate in brain tissue. In the final set of experiments, we evaluated whether $\beta$-arrestin 2 and mGlu5 receptors biochemically associate in brain tissue. Immunoprecipitation of $\beta$ arr2 protein from wild-type mice yielded positive immunoreactivity for mGluR5 monomers $(150 \mathrm{kDa})$ in western blots from cortex and hippocampus but not cerebellum. Monomeric mGluR5 protein was not detected following immunoprecipitation by an IgG isotype antibody $(n=5$, representative blot in Fig. 6i, uncropped blot provided in Supplementary Fig. 5). Similarly, mGluR5 was not detected in co-immunoprecipitation studies performed using tissue from mGluR5 ${ }^{-/-}$mice $(n=3$, representative blot in Supplementary Fig. 6). mGlu5 receptor immunoreactivity in lysate preparations from wild-type and mGluR5 ${ }^{-1-}$ tissue confirmed the absence of mGluR5, while ßarr2 was detected in the immunoprecipitation and input conditions for both genotypes. These data indicate that $\beta$ arr2 and mGluR5 associate in the hippocampus and cortex.

\section{Discussion}

Here we report that $\beta$-arrestin2 scaffolding proteins are required for some forms of mGluR-dependent excitatory synaptic plasticity at two hippocampal synapses. The observation that non-canonical $\mathrm{G}$ protein-independent signalling shapes hippocampal synaptic plasticity expands our understanding of the molecular substrates for learning and memory. $\beta$-arrestin 2 transduces a form of mGluR1-dependent plasticity of mossy fibre-CA3 synaptic currents that requires MAPK/ERK and Src kinases as downstream effectors. In contrast, classical mGluR-independent mossy fibre LTP did not require either $\beta$-arrestin isoform. Some cell-intrinsic responses to mGlu1 receptor activation in CA3 pyramidal neurons, specifically reduced initial spike frequency and transient hyperpolarizing potentials, also were not dependent on $\beta$-arrestin2, whereas elimination of $\beta$-arrestin2 altered rebound depolarization with prolonged DHPG application. In the Sch-CA1 hippocampal pathway, LTD induced by synaptic stimulation is impaired in $\beta$-arrestin2 gene targeted mice and prevented by mGluR5 antagonism. These results show that neuronal mGluR stimulation of $\beta$-arrestin signalling occurs at multiple sites in the central nervous system and comprise alternate molecular pathways that could be targeted to treat neuropathological conditions involving group I mGluRs.

Why has group I mGluR- $\beta$-arrestin2 signalling at central synapses largely escaped detection to date? First, signal transduction by arrestins has gradually gained wider recognition through pioneering studies with a number of family A and family B 7TMRs over the last 15 years, but analogous evidence linking mGluRs and other family C 7TMRs with arrestins is limited: calcium sensing receptor and mGlu7 receptor function are sensitive to $\beta$-arrestin knockdown or overexpression ${ }^{32-34}$, whereas $\mathrm{GABA}_{\mathrm{B}}$ receptors do not appear to associate with or initiate $\beta$-arrestin-mediated trafficking or signal transduction ${ }^{35}$. Second, in previous studies $\mathrm{G}$ protein-independent signalling has been associated experimentally with mGlul receptors rather than mGluR5 (ref. 2), and the latter has received significantly greater scrutiny in part because of its linkage with Fragile X Syndrome ${ }^{36}$. Third, the convergence of $G$ protein- and $\beta$-arrestin-mediated pathways on common downstream effectors, especially MAPK and Src kinases, likely obscured contributions from $\beta$-arrestin signalling in some experimental models. Fourth, the group I mGluR agonist DHPG appears to preferentially activate $G$ protein signalling while minimally stimulating $\beta$-arrestin pathways downstream of mGlu1 receptors ${ }^{37,38}$, which could also account for the divergence between DHPG- and synaptic stimulation-induced effects observed in our studies. It will be of interest to determine what roles $\beta$-arrestins have in other forms of $G$ protein-independent signalling by mGluRs that have been described in hippocampal pyramidal cells ${ }^{2,3,5}$, hippocampal interneurons ${ }^{4}$ and cerebellar interneurons 6 .

mGluR1-arrestin studies in non-neuronal heterologous expression systems and primary neuronal cultures provide important insights regarding the relationship between mGluR1 and $\beta$-arrestin 1 and are useful to interpret the present observations in slices. Recombinant $\beta$-arrestin1 translocates to and co-localizes with recombinant mGlul receptors with agonist stimulation ${ }^{39}$, and co-localization could reflect association between $\beta$-arrestin 1 and mGlu1 receptors based on co-immunoprecipitation studies ${ }^{39,40}$. $\beta$-arrestin 1 also contributes to ERK1 and ERK2 phosphorylation stimulated by receptor activation, and sustained pERK, mediated by $\beta$-arrestin 1 , has been linked to promoting cell survival ${ }^{13,14}$. Collectively these studies point towards a role for $\beta$-arrestin 1 in mGlu1 receptor signal transduction that could exist in parallel with the mGlu1- $\beta$ arrestin2 signalling manifested as changes in plasticity and intrinsic excitability that we described in the current study. Moreover, splice variations in the carboxy terminus of the mGluRs could confer an additional level of specificity in their interactions with $\beta$-arrestin isoforms to differentially impact distinct aspects of cell signalling. While still speculative for the $\beta$-arrestins, an analogous degree of specificity occurs for the interacting proteins Homer and tamalin, which specifically associate with the mGluRla splice variant due to the presence of a binding site not found in other receptor isoforms ${ }^{41,42}$.

We propose that PP-LFS induces formation of post-synaptic mGluR1, $\beta$-arrestin2, MEK, and Src complexes as a requisite step to strengthen mossy fibre-CA3 synaptic transmission, as $\beta$-arrestin2 scaffolding of MAPK/ERK 8,43 and $\mathrm{Src}^{44}$ is regulated by other 7TMRs, in addition to other kinases such as $\mathrm{JNK}^{45}$ and Akt/GSK3 (ref. 46). Unexpectedly, we found no evidence that c-Raf underlies mGluR1- and $\beta$-arrestin2- dependent plasticity, despite the requirement for ERK activation and scaffolding of c-Raf by $\beta$-arrestin 2 in in vitro systems ${ }^{15}$. One micromolar GW5074, which we used to inhibit c-Raf and b-Raf kinases, significantly attenuates pERK upregulation in slices stimulated by phorbol ester application (Supplementary Fig. 7). The data suggest that other GW5074-insensitive MEK activators, such as the mixed-lineage kinases, protein kinase $\mathrm{A}$ or PKLD ${ }^{16-18}$, have a predominant role in regulating the ERK module in this context.

How might MAPK/ERK and Src kinase activation produce their effects on mossy fibre EPSCs? In light of a possible presynaptic, mossy fibre terminal locus of expression for intermediate-term potentiation $^{3}$, Src or ERK might target trans-synaptic signalling pathways to modulate vesicle release. For example, Src or MAPK/ ERK may target the Eph-ephrin pathway, which has been proposed in classical mfLTP as a critical bidirectional transduction mechanism that bridges post-synaptic induction machinery with a presynaptic locus of expression ${ }^{47}$. MAPK/ERK could also stimulate rapid protein synthesis that ultimately modifies preand post-synaptic function. In CA3 neurons, ERK promotes phosphorylation of eukaryotic initiation factor 4E (eIF4E), NMDA receptor $2 \mathrm{~B}(\mathrm{GluN} 2 \mathrm{~B})$ protein levels and transcription of ephrinB2 (ref. 48), thereby achieving indirect modulation of post-synaptic ion channel density and trans-synaptic signalling mechanisms to impact synaptic transmission.

Transduction of mGluR1-dependent synaptic plasticity by $\beta$-arrestin 2 could also occur through signalling events restricted to the post-synaptic compartment. In CA3 neurons, calcium influx via L-type calcium channels or release from intracellular stores is required for potentiation of mfEPSCs by low-frequency synaptic stimulation ${ }^{3}$, but the precise relationship between post-synaptic calcium mobilization and $\beta$-arrestin-mediated signalling mechanisms remains unclear. Calcium influx might 
contribute to a parallel, G protein- or Homer-mediated pathway to impact plasticity; alternatively, $\beta$-arrestin2 association with the calcium effectors calmodulin and CaMKII (ref. 49) could have a role in signal transduction through mechanisms we have not explored in this study. mGluR1- $\beta$-arrestin2-Src signalling, perhaps facilitated by an increase in intracellular calcium, could modulate synaptic ionotropic receptor function. For example, transient potentiation of NMDA receptor-mediated currents by pharmacological activation of mGluR1 is GDP $\beta S$-resistant and requires Src tyrosine kinases ${ }^{2}$, and PP-LFS at mossy fibre-CA3 synapses produces sustained potentiation of NMDA receptormediated currents ${ }^{3}$ while potentiation of the AMPA/kainate mediated component of the mfEPSC requires post-synaptic Src (Fig. 2). mGlu1 receptor regulation of NMDA receptor currents in CA3 pyramidal neurons might, therefore, occur through $\beta$-arrestin2 and Src via direct, post-translational modification (for example, phosphorylation) of NMDA receptors to enhance their conductance and thereby influence other forms of mossy fibre$\mathrm{CA} 3$ plasticity $^{50}$. Alternatively, cytoskeletal reorganization of the post-synaptic compartment induced by mGluR1 and $\beta$-arrestin2 could occur through regulation of cofilin. mGlu7 receptors, for example, elicit $\beta$-arrestin2-dependent ERK phosphorylation and subsequent NMDA receptor current reduction through reduced NMDA receptor surface expression mediated by actin and cofilin $^{51}$. mGluR- $\beta$-arrestin2-cofilin regulation of the surface localization of ionotropic receptors might therefore serve as another mechanism of plasticity.

The mGluR1- and Barr2-dependent plasticity we describe here represents a mechanism for synaptic strengthening of mossy fibres that is distinct from previously described mGluR5-dependent forms of post-synaptic NMDA-LTP in several key aspects ${ }^{10,52}$. The latter is elicited by a higher-frequency pattern of synaptic stimulation ( 25 or $50 \mathrm{~Hz}$ bursts for $\sim 1 \mathrm{~s}$ ), requires activation of NMDA receptors, mGlu5 receptors and $\mathrm{A}_{2 \mathrm{~A}}$ adenosine receptors, is $G$ protein-dependent, and leads to a selective and stable potentiation of NMDA receptor EPSCs at mossy fibre synapses $^{10,52}$. In contrast, mGlul receptor-dependent plasticity is evoked by a longer, low-frequency patterned stimulation in which the precise timing of the paired stimuli appears to be an important parameter, is independent of NMDA receptor activation, requires $\beta$-arrestin2, strengthens both AMPA and NMDA receptor components of the mossy fibre EPSC, and is only operative for $<1 \mathrm{~h}$ following train stimulation ${ }^{3}$. Thus, these forms of plasticity can be viewed as complementary with regards to the duration of their effects on synaptic strength, the molecular mechanisms of induction, and the pattern of mossy fibre stimulation required for potentiation. Within the CA3 pyramidal neuron, there are points of convergence in signalling: both require Src kinase as a necessary component and both lead to enhanced NMDA contributions to mossy fibre EPSCs. Potentiation of mossy fibre NMDA-EPSCs leads to metaplasticity of both mossy fibre ${ }^{53}$ and associational/ commissural synaptic inputs ${ }^{54}$, and, therefore, the complementary mGlu receptor-dependent signalling pathways are likely to be key mechanisms for dynamic modulation of excitatory synapses in CA3 pyramidal neurons.

$\beta$-arrestin2 also appears to be necessary for synaptic stimulation-induced LTD at Sch-CA1 pyramidal cell synapses. Activation of post-synaptic group I mGluRs by PP-LFS causes LTD that is at least partially supported by presynaptic mechanisms ${ }^{55}$, whereas internalization of AMPA and NMDA receptors occurs post-synaptically ${ }^{56}$. Our data suggest that $\beta$-arrestin2 is engaged downstream of mGluR5 activation; the biochemical association that we observed between $\beta$-arrestin2 and mGlu5 receptors is consistent with a potential post-synaptic scaffolding role for $\beta$-arrestin2. mGluR5 and post-synaptic $\beta$-arrestin2 could promote receptor internalization through
MAPK/ERK and JNK and by regulation of local synthesis of endocytic machinery such as Arc; MAPK/ERK, JNK1, Arc, and protein synthesis have all been implicated in mGluR $\mathrm{LTD}^{22,26,27,57}$. Post-synaptic mGlu5 receptors directly associated with $\beta$-arrestin2 could also target trans-synaptic Eph-ephrin pathways $^{58}$ or stimulate endocannabinoid release in the hippocampus by a yet unidentified mechanism ${ }^{59}$. Alternatively, or even concurrently, mGlu5 receptors could stimulate $G$ proteincoupled mechanisms to produce endocannabinoids that then activate CB1 receptors located on excitatory presynaptic terminals ${ }^{60}$. Presynaptic $\beta$-arrestin2 could have a critical role in conjunction with $\mathrm{CB} 1$ receptors to depress neurotransmitter release, either by mediating receptor internalization ${ }^{61}$ or by formation of an active signalling complex. The multifaceted signal transduction roles that $\beta$-arrestin2 could assume in conjunction with mGlu5 receptors, which might involve interplay with endocannabinoid signalling systems and Homer proteins, could have broader implications for neuropsychiatric diseases such as Fragile X syndrome ${ }^{62,63}$ and, therefore, merits additional investigation ${ }^{64}$.

Generation of biased ligands that preferentially promote $G$ protein- or arrestin-dependent signalling afford the possibility of unprecedented fine-tuning of signalling downstream of 7TMs. Exploration of ligand bias for mGluR signalling is at a nascent stage, however. In cell culture models of mGluR1 regulation of cell viability, compounds such as DHPG, quisqualate and ACPD (1-amino-1,3-dicarboxycyclopentane) preferentially activate phosphoinositide hydrolysis (indicative of G-protein signalling) and minimally stimulate $\beta$-arrestin pathways. In the experiments presented here, DHPG LTD was intact in $\beta$-arrestin2 knockout mice, which is consistent with its induction relying on G protein-dependent mechanisms. However, it is also possible that DHPG activation of non-synaptic group I mGluRs led to induction of LTD via a divergence of signalling mechanisms compared with those regulated by PP-LFS. In contrast to DHPG, quisqualate, and ACPD, glutamate and aspartate elicit 'balanced' $G$ protein and arrestin responses, whereas succinate and glutarate were identified as arrestin'biased' agonists ${ }^{37,38}$. We also attempted to test if the putative arrestin-biased agonist succinate altered mf-CA3 EPSCs, but $1 \mathrm{mM}$ succinate application had no effect on mfEPSC amplitudes evoked at basal frequency or on the potentiation of EPSCs induced by PP-LFS (Supplementary Fig. 8). Further development appears warranted given our evidence for an important role of $\beta$-arrestins in multiple forms of group I mGluR signalling.

Regulation of divergent cellular responses by distinct mGluR signalling modalities suggests that selective targeting of effector pathways with novel drug compounds could be a useful therapeutic strategy. Biased signalling by mGlul receptors via G-protein or $\beta$-arrestin pathways has been proposed to be regulated by ligands via specific interactions within the ligand binding domain ${ }^{37}$. Whereas selective targeting of mGluR1- $\beta$ arrestin1 signalling could be used to regulate cell cycle and potentially treat some forms of cancer ${ }^{38,65}$, targeting of specific mGluR1 signalling modes in the nervous system might have some utility in treating conditions such as cerebellar ataxia ${ }^{66}$ and chronic pain ${ }^{67}$. Drugs that interfere selectively with mGluR5- $\beta$ arrestin effectors, should those prove to exist, could have potential in therapeutic targeting of Fragile $\mathrm{X}$ syndrome ${ }^{68}$. In addition to orthosteric ligands, allosteric modulators may lead to biased signalling properties as well. For example, an allosteric modulator for mGlu5 receptors with antipsychotic properties exhibited stimulus bias, potentially through enhanced coupling to $G_{q}$, was recently described ${ }^{69}$. There are no analogous biased allosteric modulators for mGlu1 receptors available, and consequently 
additional tool development will be required in order to test the viability of biased allosterism as a therapeutic approach.

These data suggest that unconventional signalling by both group I mGluR subtypes can be found at hippocampal synapses. Further delineation of the synaptic and non-synaptic roles played by $\beta$-arrestin 1 and $\beta$-arrestin 2 downstream of group I mGluR activation, enabled by future development of orthosteric ligands or allosteric modulators, could yield new targets for treatment of neurological disease and provide new insights into the molecular and cellular mechanisms of learning and memory.

\section{Methods}

Hippocampal slice preparation and electrophysiological recordings. For electrophysiological recordings, acute hippocampal slices were prepared from juvenile (P16-P22 for mossy fibre-CA3 patch-clamp recordings, P16-P25 for Sch-CA1 recordings) $\mathrm{C} 57 \mathrm{bl} / 6, \beta a \mathrm{arr}^{-1-}$, or $\beta \mathrm{arr} 2^{-1-}$ mice of either gender, in accordance with Institutional Animal Care and Use Committee-approved protocols. Barrl and Barr2 gene targeted mouse lines were generously provided by the laboratory of Dr Robert Lefkowitz of Duke University. Genotyping was performed by Transnetyx (Memphis, TN) and heterozygous by heterozygous breeders were used to raise mixed wild-type and knockout litters. In all of the comparative physiological studies, experimenters were blinded to mouse genotype or drug condition until data analysis was completed.

Mice were transcardially perfused with ice-cold sucrose-rich slicing artificial cerebrospinal fluid (aCSF) containing $85 \mathrm{mM} \mathrm{NaCl}, 2.5 \mathrm{mM} \mathrm{KCl}, 1.25 \mathrm{mM}$ $\mathrm{NaH}_{2} \mathrm{PO}_{4}, 25 \mathrm{mM} \mathrm{NaHCO}, 75 \mathrm{mM}$ sucrose, $25 \mathrm{mM}$ glucose, $10 \mu \mathrm{M}$ DL-APV, $100 \mu \mathrm{M}$ kynurenate, $0.5 \mathrm{mM} \mathrm{Na}$ L-ascorbate, $0.5 \mathrm{mM} \mathrm{CaCl}_{2}$, and $4 \mathrm{mM} \mathrm{MgCl}_{2}$, and oxygenated and equilibrated with $95 \% \mathrm{O}_{2} / 5 \% \mathrm{CO}_{2}$. Following perfusion, mice were decapitated and brains were sliced in sucrose-aCSF. Horizontal slices $(350 \mu \mathrm{m})$ preserving the ventral hippocampus were obtained using a Leica VT1200S vibratome (Leica Biosystems, Buffalo Grove, IL). Hippocampal sections were warmed to $30^{\circ} \mathrm{C}$ in sucrose-aCSF and returned to room temperature; they were then transferred to oxygenated aCSF containing $125 \mathrm{mM} \mathrm{NaCl}, 2.4 \mathrm{mM} \mathrm{KCl}$, $1.2 \mathrm{mM} \mathrm{NaH}_{2} \mathrm{PO}_{4}, 25 \mathrm{mM} \mathrm{NaHCO}_{3}, 25 \mathrm{mM}$ glucose, $2 \mathrm{mM} \mathrm{CaCl}_{2}$, and $1 \mathrm{mM}$ $\mathrm{MgCl}_{2}$ and maintained under these incubation conditions for at least $1 \mathrm{~h}$ before recording. Following incubation, individual slices were transferred to a recording chamber and continuously perfused with oxygenated aCSF at room temperature $\left(25^{\circ} \mathrm{C}\right)$. Hippocampal CA1 and CA3 pyramidal neurons were visually identified using a BX51WI fixed-stage upright microscope (Olympus, Center Valley, PA) and subsequently used for whole-cell patch clamp recordings with a MultiClamp 700A amplifier (Molecular Devices, Sunnyvale, CA).

For voltage clamp recordings, recording electrodes were pulled borosilicate glass with tip resistances of 3-7 M $\Omega$ and filled with an internal recording solution containing $95 \mathrm{mM}$ CsF, $25 \mathrm{mM} \mathrm{CsCl}, 10 \mathrm{mM}$ Cs-HEPES, $10 \mathrm{mM}$ Cs-EGTA, $2 \mathrm{mM}$ $\mathrm{NaCl}, 2 \mathrm{mM}$ Mg-ATP, $10 \mathrm{mM}$ QX-314, $5 \mathrm{mM}$ TEA-Cl and $5 \mathrm{mM}$ 4-AP, and adjusted to $\mathrm{pH} 7.3$ with $\mathrm{CsOH}$. All cells were held at $-70 \mathrm{mV}$ for the duration of voltage-clamp experiments; in addition, series resistance was continuously monitored and compensated $65-70 \%$.

Baseline mossy fibre-CA3 and Sch-CA1 EPSC amplitudes were obtained by delivering paired $(40 \mathrm{~ms}$ interstimulus interval) electrical stimulation at a basal frequency $(0.05 \mathrm{~Hz})$ using a glass monopolar electrode, positioned in the stratum lucidum or the stratum radiatum, respectively (Figs 1a and 5a). In all of the recordings excitatory transmission was isolated using $\mathrm{GABA}_{\mathrm{A}}$ receptor antagonists bicuculline $(10 \mu \mathrm{M})$ and picrotoxin $(50 \mu \mathrm{M})$, and NMDA receptor antagonist D-APV $(50 \mu \mathrm{M})$. Mossy fibre inputs were verified by short and stable latency, robust paired pulse facilitation during baseline recording $(>1.8)$, and inhibition $(>65 \%)$ by group II mGluR agonist DCG-IV $(1 \mu \mathrm{m})$, bath applied at the end of each recording.

Plasticity of Sch-CA1 and mossy fibre-CA3 synapses was induced electrically using previously characterized stimulation protocols. Protocols were executed using pClamp9 software (Molecular Devices) and an A310 Accupulser driving a D53 constant current isolated stimulator (Digitimer, Welwyn Garden City, United Kingdom). Intermediate-term potentiation of mossy fibre EPSCs was induced by lowfrequency stimulation consisting of a single train of paired stimuli $(40 \mathrm{~ms}$ interstimulus interval) delivered at $1 \mathrm{~Hz}$ for $2 \mathrm{~min}$, while mossy fibre long-term potentiation was induced by HFS (three $100 \mathrm{~Hz}$ trains, $1 \mathrm{~s}$ each delivered in $10 \mathrm{~s}$ intervals). mGluRdependent LTD of Sch-CA1 synapses was induced by PP-LFS $(1 \mathrm{~Hz}, 15 \mathrm{~min}, 50 \mathrm{~ms}$ interstimulus interval) or bath application of DHPG $(100 \mu \mathrm{M}, 5 \mathrm{~min})$ while in the presence of NMDA receptor antagonist D-APV and $\mathrm{GABA}_{\mathrm{A}} \mathrm{R}$ antagonists.

In current clamp recordings, a potassium gluconate internal solution containing $130 \mathrm{mM}$ K-gluconate, $20 \mathrm{mM} \mathrm{KCl}, 1 \mathrm{mM}$ K-HEPES, $0.2 \mathrm{mM}$ EGTA, $0.3 \mathrm{mM} \mathrm{Na}-$ GTP, $4 \mathrm{mM} \mathrm{Mg-ATP} \mathrm{pH} 7.3$ was loaded into recording electrodes. After break-in, CA3 neurons were equilibrated with the internal solution for $10 \mathrm{~min}$ and maintained in aCSF containing MTEP and CNQX. Membrane potential was held at $-70 \mathrm{mV}$ between suprathreshold current injections; the amount of current injected was calibrated to generate between 4-6 action potentials during each pre-DHPG step. Ten trains of action potentials were evoked by current steps provided at $0.05 \mathrm{~Hz}$. Cells were then measured in gap-free for $5 \mathrm{~min}$ before DHPG application; during this time the initial current required to hold at $-70 \mathrm{mV}$ was not changed. After $5 \mathrm{~min}$ of DHPG application, cells were held at $-70 \mathrm{mV}$ and 10 trains of action potentials were elicited by the same amount of current injection used before DHPG application.

Biochemical associations of endogenous proteins. To assay associations between native mGlu1 and mGlu5 receptors with $\beta$-arrestin2 proteins, mice were anesthetized with isoflurane and decapitated. Brains were dissected in ice-cold phosphatebuffered saline. Tissue from cortex, hippocampus, and cerebellum were homogenized in lysis buffer containing $25 \mathrm{mM}$ Tris, $150 \mathrm{mM} \mathrm{NaCl}, 1 \mathrm{mM}$ EDTA, $1 \mathrm{mM}$ phenylmethylsulfonyl fluoride, $1 \mathrm{mM} \mathrm{Na} \mathrm{VO}_{4}, 1 \mathrm{mM} \mathrm{NaF}, 1 \%$ Triton X-100, and protease inhibitor cocktail (P2714, Sigma-Aldrich, St Louis, MO) and rotated end over end for $25 \mathrm{~min}$. Solubilized homogenates were then clarified by centrifugation and lysate protein content was measured by Bradford assays using a spectrophotometer (Eppendorf, Hauppauge, NY). One milligram of protein from each sample was then pre-cleared using $40 \mu \mathrm{l}$ protein A/G beads (20421, Thermo Scientific, Bannockburn, IL) for $1 \mathrm{~h}$, rotating end over end at $4{ }^{\circ} \mathrm{C}$. Pre-clearing beads were discarded and $50 \mu \mathrm{l}$ of protein A/G bead slurry and rabbit polyclonal anti- $\beta$ arr2 antibody $\left(0.02 \mu \mathrm{gl}^{-1}\right.$; ab31294; Abcam, Cambridge, MA) or rabbit IgG antibody $\left(0.02 \mu \mathrm{gl}^{-1}\right.$; DA1E; Cell Signaling Technology, Danvers, MA) were added to the supernatant. Co-immunoprecipitation by $\beta$ arr2 or rabbit IgG was performed overnight at $4{ }^{\circ} \mathrm{C}$ rotating end over end. Proteins immobilized on the antibodyconjugated beads were eluted with a mixture of $2 \times$ Laemmli buffer with $\beta$-mercaptoethanol and separated by SDS-polyacrylamide gel electrophoresis in an $8 \%$ polyacrylamide gel. Following this, proteins were transferred to a polyvinylidene difluoride membrane, blocked in 5\% milk in tris-buffered saline, $0.1 \%$ Tween 20 (TBS-T), and immunoblotted using mouse anti-mGluR1 $\left(0.05 \mu \mathrm{g} \mathrm{ml}^{-1} ; 610964 ; \mathrm{BD}\right.$ Biosciences, San Jose, CA), rabbit anti-mGluR5 $\left(0.2 \mu \mathrm{g} \mathrm{ml}^{-1}\right.$; AB5675; EMD Millipore, Billerica, MA) or rabbit anti- $\beta$ arr2 $\left(0.125 \mu \mathrm{g} \mathrm{ml}^{-1}\right)$ antibodies. Pulldown of proteins was visualized using HRP-conjugated goat anti-mouse and goat anti-rabbit secondary antibodies (GE Healthcare, Little Chafont, United Kingdom) with enhanced chemiluminescence (ECL) substrate (Pierce ECL Western Blotting Substrate, Thermo Scientific, Bannockburn, IL).

Surface biotinylation. Acute brain slices were prepared as described for physiology. After $1 \mathrm{~h}$ of incubation at room temperature, slices were transferred into 6-well plates containing $0.5 \mathrm{mg} \mathrm{ml}^{-1}$ sulfo-NHS-LC-Biotin (21335; Pierce) in aCSF, on ice. Dissected hippocampi were biotinylated for $30 \mathrm{~min}$ and were subsequently washed twice with $\mathrm{NH}_{4} \mathrm{Cl}(50 \mathrm{mM})$-supplemented aCSF and twice with aCSF, then homogenized in $1 \mathrm{ml}$ of homogenization buffer $(10 \mathrm{mM}$ Tris, $320 \mathrm{mM}$ sucrose, protease inhibitors, $\mathrm{pH}=7.4$ ). Samples were clarified by centrifugation at $1,000 \mathrm{~g}$ for $5 \mathrm{~min}$ and supernatants were collected for centrifugation at $100,000 \mathrm{~g}$ for $1 \mathrm{~h}$. Pellets were then resuspended in $500 \mu \mathrm{l}$ lysis buffer containing $20 \mathrm{mM}$ HEPES, $150 \mathrm{mM}$ $\mathrm{NaCl}, 2 \mathrm{mM}$ EDTA, $1 \%$ Triton X-100, $0.1 \%$ SDS and protease inhibitors with a $\mathrm{pH}$ of 7.4 and sonicated. Samples were rotated end over end for $2 \mathrm{~h}$ at $4{ }^{\circ} \mathrm{C}$; following solubilization, samples were centrifuged for $40 \mathrm{~min}$ at $100,000 \mathrm{~g}$. The supernatants were subsequently collected and the protein concentration was measured. Threehundred micrograms of protein brought to a $300 \mathrm{ml}$ final volume from each mouse was then incubated with $40 \mu \mathrm{l}$ of washed streptavidin-Sepharose beads (17-5113-01; GE Healthcare) overnight at $4{ }^{\circ} \mathrm{C}$. Streptavidin immunoprecipitation samples were centrifuged at $1,000 \mathrm{~g}$ for $3 \mathrm{~min}$ and the supernatant (non-biotinylated fraction) was collected. The Sepharose beads bound to the biotinylated fraction were washed three times with lysis buffer and $150 \mu \mathrm{l}$ of $2 \times$ Laemmli sample buffer (Bio-Rad) with $\beta$-mercaptoethanol was added. The protein samples were agitated and boiled at $95^{\circ} \mathrm{C}$ for $5 \mathrm{~min}$ and samples were frozen or used immediately for gel electrophoresis. Antibodies raised against mGluR5 $\left(0.2 \mu \mathrm{g} \mathrm{ml}^{-1}\right)$, GluK2 (1:10,000; clone NL9, 04-921; EMD Millipore), and $\beta$-tubulin $(1: 10,000)$ were used to measure immunoreactivity for the respective proteins by western blotting. Film obtained following western blotting was scanned and optical densities were measured using ImageJ.

Statistical analysis. Non-parametric Mann-Whitney tests were used to compare mean post-train amplitudes and mean baseline PPRs between genotypes or drugtreated groups; Wilcoxon tests were used to compare baseline versus peak DHPG application responses. Mean \pm s.e.m. is provided throughout the text. EPSC amplitude time courses are represented as mean \pm s.e.m., while baseline PPRs are shown with median and inter-quartile ranges. All box and whisker plots are represented as median, interquartile range and $10-90 \%$ percentiles.

Pharmacological compounds. The following compounds were either bath applied with aCSF or used to supplement the recording internal solution during pharmacology experiments: PP2 $(20 \mu \mathrm{M})$, pp60 ${ }^{\text {cSrc }} 521-533$, phosphorylated $(200 \mu \mathrm{M}), \mathrm{u} 0126(20 \mu \mathrm{M})$, GW5074 $(1 \mu \mathrm{M}),(S)-3,5$-DHPG $(50-100 \mu \mathrm{M})$, MTEP $(1 \mu \mathrm{M}),(+)$-2-methyl-4-carboxyphenylglycine (LY367385, $50 \mu \mathrm{M})$ and CNQX $(50 \mu \mathrm{M})$. CNQX was purchased from Sigma-Aldrich. DHPG, MTEP and LY367385 were purchased from Abcam; all other pharmacological agents were purchased from Tocris Bioscience (Bristol, UK).

Data availability. The data that support the findings of this study are available from the authors on reasonable request. 


\section{References}

1. Niswender, C. M. \& Conn, P. J. Metabotropic glutamate receptors: physiology, pharmacology, and disease. Annu. Rev. Pharmacol. Toxicol. 50, 295-322 (2010).

2. Benquet, P., Gee, C. E. \& Gerber, U. Two distinct signaling pathways upregulate NMDA receptor responses via two distinct metabotropic glutamate receptor subtypes. J. Neurosci. 22, 9679-9686 (2002)

3. Frausto, S. F. et al. A novel form of low-frequency hippocampal mossy fiber plasticity induced by bimodal mGlu1 receptor signaling. J. Neurosci. 31, 16897-16906 (2011).

4. Gee, C. E. \& Lacaille, J. C. Group I metabotropic glutamate receptor actions in oriens/alveus interneurons of rat hippocampal CA1 region. Brain Res. 1000, 92-101 (2004)

5. Heuss, C. et al. G-protein-independent signaling mediated by metabotropic glutamate receptors. Nat. Neurosci. 2, 1070-1077 (1999).

6. Kubota, H. et al. mGluR1-mediated excitation of cerebellar GABAergic interneurons requires both $\mathrm{G}$ protein-dependent and Src-ERK1/2-dependent signaling pathways. PLOS ONE 9, e106316 (2014)

7. Luttrell, L. M. et al. Beta-arrestin-dependent formation of beta2 adrenergic receptor-Src protein kinase complexes. Science 283, 655-661 (1999).

8. Wei, H. et al. Independent beta-arrestin 2 and $G$ protein-mediated pathways for angiotensin II activation of extracellular signal-regulated kinases 1 and 2. Proc. Natl Acad. Sci. USA. 100, 10782-10787 (2003).

9. Daniel, H., Levenes, C. \& Crepel, F. Cellular mechanisms of cerebellar LTD. Trends Neurosci. 21, 401-407 (1998).

10. Kwon, H. B. \& Castillo, P. E. Long-term potentiation selectively expressed by NMDA receptors at hippocampal mossy fiber synapses. Neuron 57, 108-120 (2008).

11. Gee, C. E., Benquet, P. \& Gerber, U. Group I metabotropic glutamate receptors activate a calcium-sensitive transient receptor potential-like conductance in rat hippocampus. J. Physiol. 546, 655-664 (2003).

12. Bain, J. et al. The selectivity of protein kinase inhibitors: a further update. Biochem. J. 408, 297-315 (2007).

13. Emery, A. C. et al. The protective signaling of metabotropic glutamate receptor 1 Is mediated by sustained, beta-arrestin-1-dependent ERK phosphorylation. J. Biol. Chem. 285, 26041-26048 (2010).

14. Iacovelli, L. et al. Role of G protein-coupled receptor kinase 4 and beta-arrestin 1 in agonist-stimulated metabotropic glutamate receptor 1 internalization and activation of mitogen-activated protein kinases. J. Biol. Chem. 278 12433-12442 (2003)

15. Luttrell, L. M. et al. Activation and targeting of extracellular signal-regulated kinases by beta-arrestin scaffolds. Proc. Natl Acad. Sci. USA. 98, 2449-2454 (2001)

16. Marusiak, A. A. et al. Mixed lineage kinases activate MEK independently of RAF to mediate resistance to RAF inhibitors. Nat. Commun. 5, 3901 (2014).

17. Gomez, E., Pritchard, C. \& Herbert, T. P. cAMP-dependent protein kinase and $\mathrm{Ca}^{2+}$ influx through L-type voltage-gated calcium channels mediate Raf-independent activation of extracellular regulated kinase in response to glucagon-like peptide-1 in pancreatic beta-cells. J. Biol. Chem. 277, 48146-48151 (2002)

18. Sato, S., Fujita, N. \& Tsuruo, T. Involvement of 3-phosphoinositide-dependent protein kinase-1 in the MEK/MAPK signal transduction pathway. J. Biol. Chem. 279, 33759-33767 (2004).

19. Hsia, A. Y. et al. Evidence against a role for metabotropic glutamate receptors in mossy fiber LTP: the use of mutant mice and pharmacological antagonists. Neuropharmacology 34, 1567-1572 (1995).

20. Brown, J. T., Booth, C. A. \& Randall, A. D. Synaptic activation of mGluR1 generates persistent depression of a fast after-depolarizing potential in CA3 pyramidal neurons. Eur. J. Neurosci. 33, 879-889 (2011).

21. Harata, N. et al. Two components of metabotropic glutamate responses in acutely dissociated CA3 pyramidal neurons of the rat. Brain Res. 711, 223-233 (1996)

22. Huber, K. M., Kayser, M. S. \& Bear, M. F. Role for rapid dendritic protein synthesis in hippocampal mGluR-dependent long-term depression. Science 288, 1254-1257 (2000).

23. Kemp, N. \& Bashir, Z. I. Induction of LTD in the adult hippocampus by the synaptic activation of AMPA/kainate and metabotropic glutamate receptors. Neuropharmacology 38, 495-504 (1999).

24. Huber, K. M., Roder, J. C. \& Bear, M. F. Chemical induction of mGluR5- and protein synthesis--dependent long-term depression in hippocampal area CA1. J. Neurophysiol. 86, 321-325 (2001)

25. Palmer, M. J. et al. The group I mGlu receptor agonist DHPG induces a novel form of LTD in the CA1 region of the hippocampus. Neuropharmacology 36, 1517-1532 (1997).

26. Gallagher, S. M. et al. Extracellular signal-regulated protein kinase activation is required for metabotropic glutamate receptor-dependent long-term depression in hippocampal area CA1. J. Neurosci. 24, 4859-4864 (2004)
27. Li, X. M. et al. JNK1 contributes to metabotropic glutamate receptor-dependent long-term depression and short-term synaptic plasticity in the mice area hippocampal CA1. Eur. J. Neurosci. 25, 391-396 (2007).

28. Nosyreva, E. D. \& Huber, K. M. Developmental switch in synaptic mechanisms of hippocampal metabotropic glutamate receptor-dependent long-term depression. J. Neurosci. 25, 2992-3001 (2005).

29. Oliet, S. H., Malenka, R. C. \& Nicoll, R. A. Two distinct forms of long-term depression coexist in CA1 hippocampal pyramidal cells. Neuron 18, 969-982 (1997).

30. Cosford, N. D. et al. 3-[(2-Methyl-1,3-thiazol-4-yl)ethynyl]-pyridine: a potent and highly selective metabotropic glutamate subtype 5 receptor antagonist with anxiolytic activity. J. Med. Chem. 46, 204-206 (2003).

31. Clark, B. P. et al. (+)-2-Methyl-4-carboxyphenylglycine (LY367385) selectively antagonises metabotropic glutamate mGluR1 receptors. Bioorg. Med. Chem. Lett. 7, 2777-2780 (1997).

32. Bouschet, T. et al. The calcium-sensing receptor changes cell shape via a beta-arrestin-1 ARNO ARF6 ELMO protein network. J. Cell Sci. 120, 2489-2497 (2007).

33. Iacovelli, L. et al. Selective regulation of recombinantly expressed mGlu7 metabotropic glutamate receptors by $\mathrm{G}$ protein-coupled receptor kinases and arrestins. Neuropharmacology 77, 303-312 (2014)

34. Pi, M. et al. Beta-arrestin- and G protein receptor kinase-mediated calciumsensing receptor desensitization. Mol. Endocrinol. 19, 1078-1087 (2005).

35. Sudo, Y. et al. GABA(B) receptors do not internalize after baclofen treatment, possibly due to a lack of beta-arrestin association: study with a real-time visualizing assay. Synapse 66, 759-769 (2012).

36. Dolen, G. \& Bear, M. F. Role for metabotropic glutamate receptor 5 (mGluR5) in the pathogenesis of fragile X syndrome. J. Physiol. 586, 1503-1508 (2008).

37. Emery, A. C. et al. Ligand bias at metabotropic glutamate 1a receptors: molecular determinants that distinguish beta-arrestin-mediated from $\mathrm{G}$ protein-mediated signaling. Mol. Pharmacol. 82, 291-301 (2012).

38. Hathaway, H. A. et al. Pharmacological characterization of mGlul receptors in cerebellar granule cells reveals biased agonism. Neuropharmacology 93, 199-208 (2015).

39. Dale, L. B. et al. Agonist-stimulated and tonic internalization of metabotropic glutamate receptor 1a in human embryonic kidney 293 cells: agonist-stimulated endocytosis is beta-arrestin1 isoform-specific. Mol. Pharmacol. 60, 1243-1253 (2001).

40. Mundell, S. J. et al. Desensitization and internalization of metabotropic glutamate receptor 1a following activation of heterologous $\mathrm{Gq} / 11$-coupled receptors. Biochemistry 43, 7541-7551 (2004).

41. Fagni, L. et al. Complex interactions between mGluRs, intracellular $\mathrm{Ca}^{2+}$ stores and ion channels in neurons. Trends Neurosci. 23, 80-88 (2000).

42. Hirose, M. et al. Phosphorylation and recruitment of Syk by immunoreceptor tyrosine-based activation motif-based phosphorylation of tamalin. J. Biol. Chem. 279, 32308-32315 (2004).

43. Shenoy, S. K. et al. $\beta$-Arrestin-dependent, G protein-independent ERK1/2 activation by the $\beta 2$ adrenergic receptor. J. Biol. Chem. 281, 1261-1273 (2006).

44. Luan, B. et al. Deficiency of a beta-arrestin-2 signal complex contributes to insulin resistance. Nature 457, 1146-1149 (2009).

45. McDonald, P. H. et al. Beta-arrestin 2: a receptor-regulated MAPK scaffold for the activation of JNK3. Science 290, 1574-1577 (2000).

46. Schmid, C. L. \& Bohn, L. M. Serotonin, but not N-methyltryptamines, activates the serotonin $2 \mathrm{~A}$ receptor via a beta-arrestin2/Src/Akt signaling complex in vivo. J. Neurosci. 30, 13513-13524 (2010).

47. Contractor, A. et al. Trans-synaptic Eph receptor-ephrin signaling in hippocampal mossy fiber LTP. Science 296, 1864-1869 (2002).

48. Nateri, A. S. et al. ERK activation causes epilepsy by stimulating NMDA receptor activity. EMBO J. 26, 4891-4901 (2007).

49. Xiao, K. et al. Functional specialization of beta-arrestin interactions revealed by proteomic analysis. Proc. Natl Acad. Sci. USA 104, 12011-12016 (2007).

50. Ali, D. W. \& Salter, M. W. NMDA receptor regulation by Src kinase signalling in excitatory synaptic transmission and plasticity. Curr. Opin. Neurobiol. 11, 336-342 (2001).

51. Gu, Z. et al. Regulation of N-methyl-D-aspartic acid (NMDA) receptors by metabotropic glutamate receptor 7. J. Biol. Chem. 287, 10265-10275 (2012)

52. Rebola, N. et al. Adenosine A2A receptors are essential for long-term potentiation of NMDA-EPSCs at hippocampal mossy fiber synapses. Neuron 57, 121-134 (2008).

53. Rebola, N. et al. NMDA receptor-dependent metaplasticity at hippocampal mossy fiber synapses. Nat. Neurosci. 14, 691-693 (2011).

54. Hunt, D. L. et al. Bidirectional NMDA receptor plasticity controls CA3 output and heterosynaptic metaplasticity. Nat. Neurosci. 16, 1049-1059 (2013).

55. Faas, G. C. et al. Modulation of presynaptic calcium transients by metabotropic glutamate receptor activation: a differential role in acute depression of synaptic transmission and long-term depression. J. Neurosci. 22, 6885-6890 (2002). 
56. Snyder, E. M. et al. Internalization of ionotropic glutamate receptors in response to mGluR activation. Nat. Neurosci. 4, 1079-1085 (2001).

57. Waung, M. W. et al. Rapid translation of Arc/Arg3.1 selectively mediates mGluR-dependent LTD through persistent increases in AMPAR endocytosis rate. Neuron 59, 84-97 (2008).

58. Piccinin, S. et al. Interaction between Ephrins and mGlu5 metabotropic glutamate receptors in the induction of long-term synaptic depression in the hippocampus. J. Neurosci. 30, 2835-2843 (2010).

59. Chevaleyre, V. \& Castillo, P. E. Heterosynaptic LTD of hippocampal GABAergic synapses: a novel role of endocannabinoids in regulating excitability. Neuron 38, 461-472 (2003).

60. Kawamura, Y. et al. The CB1 cannabinoid receptor is the major cannabinoid receptor at excitatory presynaptic sites in the hippocampus and cerebellum. J. Neurosci. 26, 2991-3001 (2006).

61. Ahn, K. H. et al. Distinct roles of beta-arrestin 1 and beta-arrestin 2 in ORG27569-induced biased signaling and internalization of the cannabinoid receptor 1 (CB1). J. Biol. Chem. 288, 9790-9800 (2013).

62. Bear, M. F., Huber, K. M. \& Warren, S. T. The mGluR theory of fragile X mental retardation. Trends Neurosci. 27, 370-377 (2004)

63. Contractor, A., Klyachko, V. A. \& Portera-Cailliau, C. Altered neuronal and circuit excitability in fragile X syndrome. Neuron 87, 699-715 (2015).

64. Luscher, C. \& Huber, K. M. Group 1 mGluR-dependent synaptic long-term depression: mechanisms and implications for circuitry and disease. Neuron 65, 445-459 (2010).

65. Gelb, T. et al. Metabotropic glutamate receptor 1 acts as a dependence receptor creating a requirement for glutamate to sustain the viability and growth of human melanomas. Oncogene 34, 2711-2720 (2015).

66. Notartomaso, S. et al. Pharmacological enhancement of mGlu1 metabotropic glutamate receptors causes a prolonged symptomatic benefit in a mouse model of spinocerebellar ataxia type 1. Mol. Brain 6, 48 (2013).

67. Chiechio, S. \& Nicoletti, F. Metabotropic glutamate receptors and the control of chronic pain. Curr. Opin. Pharmacol. 12, 28-34 (2012).

68. Dolen, G. et al. Correction of fragile X syndrome in mice. Neuron 56, 955-962 (2007).

69. Rook, J. M. et al. Biased mGlu5-positive allosteric modulators provide in vivo efficacy without potentiating mGlu5 modulation of NMDAR currents. Neuron 86, 1029-1040 (2015)

\section{Acknowledgements}

We wish to thank the laboratory of Dr Robert Lefkowitz of Duke University for the $\beta a r r 1^{-/-}$and $\beta$ arr2 ${ }^{-/-}$mice. We are also deeply grateful for comments and advice from members of the Swanson laboratory and Drs Anis Contractor, Herman Fernandes, and Jian Xu. We also wish to thank Dr Antonio Sanz-Clemente for the gracious use of his equipment and facilities. This work was supported by a National Institutes of Neurological Diseases and Stroke (NINDS) grant to G.T.S. (R21NS088916-01).

\section{Author contributions}

Conceptualization: G.T.S.; Methodology: G.T.S. and A.G.E.; Formal analysis: G.T.S. and A.G.E.; Investigation: A.G.E., D.A.K. and T.P.H.; Writing-original draft: G.T.S. and A.G.E.; Writing—review and editing: G.T.S., A.G.E. and T.P.H.; Funding acquisition G.T.S.; Supervision: G.T.S

\section{Additional information}

Supplementary Information accompanies this paper at http://www.nature.com/ naturecommunications

Competing financial interests: The authors declare no competing financial interests.

Reprints and permission information is available online at http://npg.nature.com/ reprintsandpermissions/

How to cite this article: Eng, A. G. et al. Transduction of group I mGluR-mediated synaptic plasticity by $\beta$-arrestin2 signalling. Nat. Commun. 7, 13571 doi: 10.1038/ ncomms13571 (2016)

Publisher's note: Springer Nature remains neutral with regard to jurisdictional claims in published maps and institutional affiliations.

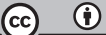

This work is licensed under a Creative Commons Attribution 4.0 International License. The images or other third party material in this article are included in the article's Creative Commons license, unless indicated otherwise in the credit line; if the material is not included under the Creative Commons license, users will need to obtain permission from the license holder to reproduce the material. To view a copy of this license, visit http://creativecommons.org/licenses/by/4.0/

(C) The Author(s) 2016 